\title{
Immobilization of Cellulolytic Enzymes in Mesostructured Silica Materials
}

\author{
Valeria Califano ${ }^{1, *}$ and Aniello Costantini ${ }^{2, *}$ \\ 1 Istituto Motori CNR, Via Guglielmo Marconi 4, 80125 Napoli, Italy \\ 2 Department of Chemical Engineering, Materials and Industrial Production, Piazzale Tecchio 80, \\ 80125 Napoli, Italy \\ * Correspondence: v.califano@im.cnr.it (V.C.); anicosta@unina.it (A.C.); \\ Tel.: +39-081-7177-226 (V.C.); +39-081-768-2596 (A.C.)
}

Received: 28 May 2020; Accepted: 18 June 2020; Published: 23 June 2020

check for updates

\begin{abstract}
Mesostructured silica nanoparticles offer a unique opportunity in the field of biocatalysis thanks to their outstanding properties. The tunable pore size in the range of mesopores allows for immobilizing bulky enzyme molecules. The large surface area improves the catalytic efficiency by increasing enzyme loading and finely dispersing the biocatalyst molecules. The easily tunable pore morphology allows for creating a proper environment to host an enzyme. The confining effect of mesopores can improve the enzyme stability and its resistance to extreme $\mathrm{pH}$ and temperatures. Benefits also arise from other peculiarities of nanoparticles such as Brownian motion and easy dispersion. Fossil fuel depletion and environmental pollution have led to the need for alternative sustainable and renewable energy sources such as biofuels. In this context, lignocellulosic biomass has been considered as a strategic fuel source. Cellulases are a class of hydrolytic enzymes that convert cellulose into fermentable sugars. This review is intended to survey the immobilization of cellulolytic enzymes (cellulases and $\beta$-glucosidase) onto mesoporous silica nanoparticles and their catalytic performance, with the aim to give a contribution to the urgent action required against climate change and its impacts, by biorefineries' development.
\end{abstract}

Keywords: cellulase; $\beta$-glucosidase; cellulolytic enzymes; mesoporous silica; enzyme immobilization; cellulose hydrolysis; biofuels

\section{Introduction}

Environmental pollution and depletion of fossil fuel reserves are today two of the main challenges we are facing. It has been predicted that the reserves of oil and natural gas will be exhausted within the next fifty years [1]. The main causes are the enormous growth of the world population, the increase in technological development, and the lifestyle in industrialized nations. Moreover, the excessive use of fossil fuels has additional negative effects on the environment such as the greenhouse effect, the phenomenon of acid rain, the depletion of the ozone layer, and the extreme climate changes. This has led to the need for alternative, environmentally sustainable, and renewable energy sources [2]. In this frame, bioethanol represents a good choice to replace fossil fuel. The most abundant organic material in the biosphere is cellulose [3-6], which represents the storage of sun energy into chemical energy. Cellulose is the main component of lignocellulosic biomass. It consists of glucose units linked by 1, 4-beta glycosidic bond. The use of waste cellulose as a raw material for the production of biofuels such as ethanol and butanol is a very promising approach to meet current and future energy demands in a sustainable way [3]. The hydrolysis of cellulose has a key role for chemical production of ethanol, as it produces sugars such as glucose that can be fermented into ethanol. The enzymatic hydrolysis of cellulose has several advantages over its chemical hydrolysis, as it allows for complex 
chemical processes under mild environmental conditions [1,2] without the necessity of using high pressures, temperatures, and harsh chemical environments, leading to high purity products. However, the fragile nature and high cost limit the use of free enzymes for industrial applications. Enzymatic immobilization on insoluble supports represents a valid solution to address these problems, as it often increases enzyme stability and enhances the enzyme thermal and $\mathrm{pH}$ stability [7]. Moreover, it allows for their easy recovery and reuse and continuous operation [3]. The mixture of enzymes capable of cellulose hydrolysis is referred to as cellulase and compises three types of enzymes: cellobiohydrolase (CBH), endoglucanase (EG), and $\beta$-glucosidase (BG) (or cellobiase) [2]. They act sequentially and synergistically on the polymeric chain of cellulose releasing glucose, which is easily fermentable to ethanol.

The methods of enzyme immobilization can be categorized into four kinds: physical adsorption, entrapment, cross-linking, and covalent attachment. Each procedure has its own advantages and drawbacks. The insoluble support for the immobilization plays a key role in preserving the activity and enhancing the stability of an enzyme. A large number of organic and inorganic supports have been used to immobilize cellulase [1,8-10]. Among them, ordered mesoporous silica materials (OMS) represent an excellent choice. OMS materials provide a unique opportunity, as they contain abundant surface silanol groups. Silanols can be functionalized with a variety of organic linkers, including amine, carboxylate, phenyl, and alkyl groups, to obtained covalent links with enzymes. Furthermore, they can allow for the physical adsorption of the enzyme by secondary interactions, such as hydrogen bonding and electrostatic forces. Moreover, the porous structure can protect the enzyme against the harsh conditions of the reaction environment, such as high temperatures, extreme $\mathrm{pH}$, and the presence of bubbles or inhibitors, creating an ideal micro-environment for the expression of the enzymatic activity [11,12]. The main technique to produce OMS is the sol-gel route. Using this route, it is possible to tune the size, shape, and morphology of the pores, by changing the synthesis parameters such as $\mathrm{pH}$, water/alcohol molar ratio, and the chemical nature of the template, allowing for a proper environment to host an enzyme. Many mesoporous silica materials have been synthesized since they were first discovered by the Mobile oil company in the 1992. Over the past fifty years, many ordered mesoporous silica materials with different size, morphology, and connectivity of their pores have been prepared and used in different fields of application as carriers for catalysts. There have been a great deal of studies to understand the requirements that the mesoporous silica substrates must possess in order to maximize both the quantity of cellulase to be immobilized and its catalytic efficiency. The results obtained highlighted the need for mesoporous silica substrates to have large pores with a three-dimensional interconnection, which allows for better mass transfer and reduces pore blocking [13], and a suitable functionalization with organic groups such as vinyl or thiol [14-16].

In the present review, the focus will be to give a broad overview of the most important aspects and critical issues concerning the immobilization of cellulase and $\beta$-glucosidase onto mesoporous silica substrates, with the aim to give a contribution to biorefineries' development as well as a perspective on new opportunities for the future.

\section{Enzyme Immobilization}

Biocatalysis has a key role for chemical production for its high stereo-, chemo-, and regioselectivity. It takes place under mild conditions, diminishing the energy consumption when compared with chemical processes $[17,18]$. However, free enzymes exhibit low stability and are difficult to recover, causing high costs and low production efficiency, making them industrially and commercially unsuitable. To address these problems, one possible solution is the immobilization of enzymes on insoluble supports. The immobilization of biocatalysts on/in a solid matrix can mitigate both problems. In fact, immobilization often results in a higher stability of the enzyme [19] and an easier separation from the reaction medium, allowing for reuse. The heterogeneous nature of this kind of catalyst also allows continuous operations. All these features contribute to offsetting the high production cost of enzymes. In 1916, Nelson and Griffin [20] first immobilized the enzyme invertase by physical 
adsorption on charcoal, demonstrating its ability to hydrolyze the sucrose. In the last thirty years, many carriers and methodologies have been used for enzyme immobilization [21,22]. The methods of enzyme immobilization can be categorized into four kinds: physical adsorption, entrapment, cross-linking, and covalent attachment. Each procedure has its own advantages and drawbacks. A schematic of immobilization methods is illustrated in Figure 1.

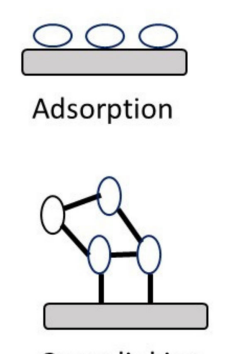

Cross-linking
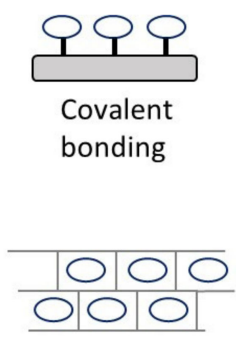

Entrapment

Figure 1. Immobilization methods.

Regardless of the method used, the immobilization should have two main effects: improve the enzyme stability to temperature and environmental factors and preserve its activity. Furthermore, the enzyme should be well anchored on the matrix, so as to avoid leaching. In this way, a conversion rate similar to the free enzyme can be assured, and reuse and continuous operation allowed.

\subsection{Adsorption}

Physical adsorption is the easiest method to immobilize an enzyme. It is based on the physical interaction between the enzyme and support, such as hydrogen bonding, electrostatic forces, or hydrophobic effects. To improve the immobilization efficiency, the surface charges of the enzyme and the support should be opposite, to obtain strong physical interactions between of them. However, the surface charge on the enzyme must not be excessive to avoid electrostatic repulsions between enzyme molecules. This can be achieved by choosing a support that has an appropriate isoelectric point and a careful regulation of the adsorption $\mathrm{pH}$. The advantage of this method lies on the mild operative conditions, which should preserve the native conformation of the enzyme. This is an important condition to keep the enzyme activity unchanged. The drawback of this method is owing to weak interactions between the enzyme and the support, which are not strong enough to keep the enzyme from desorbing from the support during catalysis. As an example, cellulase from Aspergillus niger was immobilized by adsorption on a commercial activated carbon, with a retention of $70 \%$ of the native enzyme activity up to five cycles of repeated batch enzyme reactions [23].

\subsection{Entrapment}

Entrapment refers to the encapsulation of an enzyme within a confined space, which allows for the substrate and products to diffuse through, but retains the enzyme. Therefore, after entrapment, the enzyme is not attached to the support, but the support acts as a physical barrier to its diffusion. It allows for new possibilities in the field of material science [24,25]. Entrapment in inorganic/organic hybrid polymer matrices represents an interesting chance to immobilize enzymes. The advantages of this method are related to both the features of the support, such as uniformity, high purity, biocompatibility, thermal, and chemical stability, and to the mild processing conditions, which should not cause any injury to the enzyme [26-28]. In particular, entrapment within a sol-gel matrix proved to be a suitable method for immobilization of a large variety of biomolecules [29]. In one of the earliest works, cellulase was entrapped in a collagen fibril matrix, showing no leaching and enhanced stability [30]. Unfortunately, this methodology has a main drawback, owing to the difficulty in having 
a proper enzyme-confining environment without creating large diffusion barriers for the transport of substrates and products.

\subsection{Cross-Linking}

Cross-linking is based on the building of big three-dimensional enzyme aggregates by linking the enzyme molecules together covalently [31]. The use of cross-linked enzyme crystals (CLECs) as industrial biocatalysts was pioneered by Altus Biologics in the 1990s. CLECs proved to be significantly more stable to denaturation by heat, organic solvents, and proteolysis than the corresponding soluble enzyme or lyophilized (freeze-dried) powder. CLECs are robust, highly active immobilized enzymes of controllable particle size, varying from 1 to 100 micrometers. Their operational stability and ease of recycling, coupled with their high catalyst and volumetric productivities, renders them ideally suited for industrial biotransformation. CLECs have a high cost of the crystallization process that requires enzymes of high purity. The more recently developed cross-linked enzyme aggregates (CLEAs) are produced by a cheaper and easier method. This method is based on precipitation and purification of the enzymes from an aqueous solution into a single unit operation that does not require a highly pure enzyme [32]. The aggregates of protein molecules precipitated from solution are held together by covalent bindings, which do not cause any perturbation of the tertiary structure of the enzyme, but render CLEAs permanently insoluble. Li et al. studied the properties of carrier-free cellulase CLEAS (C-CLEAS) [33]. C-CLEAS were prepared by precipitation with ammonia sulfate and cross-linking with glutaraldehyde. An efficient enzyme activity was obtained. This technique has some drawbacks, such as the impossibility to control the size of the aggregates, the difficult diffusion of the substrate to the core of the aggregates, and the lack of mechanical strength of the cross-linked enzyme. In order to solve these problems, this technique can be combined with other enzyme immobilization procedures. For example, the enzymes can first be physically adsorbed in a three-dimensional network of interconnecting cages, with diameters several times the size of the enzyme, and then they can be cross-linked. In this way, the size of enzyme aggregates is controlled by the size of the cage. The smaller dimension of aggregates allows for an easier diffusion of the substrate inside the core of the enzyme aggregates. Moreover, the scaffold allows for improved mechanical strength of the enzyme aggregates. A proper tuning of the size of the cage interconnections can reduce the leaching of the enzyme aggregates.

\subsection{Covalent Bonding}

Enzyme immobilization by covalent bonding to an insoluble support has the advantage of irreversible binding of the enzyme to the matrix. The major advantage of covalent binding is the stability of the immobilized enzyme, thus minimizing enzyme leaching. Ordered mesoporous silica provides excellent opportunities for the immobilization of the enzymes via covalent binding owing to the availability of well-defined silanol groups. These groups provide reactive sites for functionalization and offer tunable surface properties [34], allowing to control the position and density of the immobilized catalyst precisely $[35,36]$. Attachment can be achieved by using crosslinking agents such as glutaraldehyde and carbodimide derivatives to covalently bind the enzyme amino acid residues such as, $\mathrm{NH}_{2}, \mathrm{CO}_{2}$, and $\mathrm{SH}$ of the enzyme to the surface of the support. The enzyme is generally anchored to the surface through one or more sites (multipoint attachment). Attachment at some of these sites can enable the enzyme to be fully catalytically efficient, whereas at other sites (i.e., the catalytic residues in the active site), the catalytic activity of the enzyme may be destroyed. A strategic method to avoid this problem is to allow for specific anchoring of the enzyme via the introduction of a histidine tag on the enzyme, using specific ligand metals such as $\mathrm{Ni}$ and $\mathrm{Co}$ [37]. It must be noted that the harsh conditions employed during covalent binding can potentially alter the enzyme conformation, thus lowering the enzymatic activity.

The activity of the immobilized enzyme is a complex parameter dependent on a number of factors, such as the immobilization method used, the surface properties and pore structure of the support, and the molecular size of the enzyme. Therefore, preparation of a biocatalyst requires a deep study of 
these factors to optimize the catalytic performance of the enzyme. The performance of an immobilized enzyme crucially depends on the features of the support material. In particular, porous supports can have high enzyme loading capacity, and the resulting immobilized system may give higher catalytic activity as a result of the shortened path of diffusion. In this context, the use of mesoporous silica-based materials offers great potential for obtaining biocatalysts with high activity and stability. In fact, these types of porous materials have high surface area and the pore size is easily controlled. The pore size is important to hinder mass transfer limitations of the substrates to the active site of the enzyme and to favor the diffusion of the products from the active site to the bulk reaction mixture. The pore size must be large enough to accommodate the enzyme and promote unrestricted diffusion of reactant and products. From this point of view, the interconnection of the pores is also an important parameter, as it promotes diffusion. In the absence of diffusion limitations, the ideal condition is reached in which the reaction rate is directly proportional to the surface area available.

\section{Mesoporous and Microporous Silica Materials}

\subsection{Silica Nanoparticles}

Zeolites and porous silica represent important porous materials owing to their wide industrial applications, for example, as molecular sieves or in the fields of catalysis and drug delivery [38]. Zeolites are crystalline aluminosilicates, first discovered in 1756 by the Swedish scientist Cronstedt. Some studies on zeolite minerals have begun since the nineteenth century, but there was a lack of general scientific interest. In 1932, McBain carried out some study on a mineral chabazite. He discovered that chabazite showed selective sorption of molecules smaller than $5 \AA$ in diameter [39]. After this study, the term molecular sieve was used to specify a class of materials that allow for a selective sorption of mixtures based on different molecular sizes and shapes. Others studies were conducted on chabazite and other porous minerals by Barrer and coworkers [40]. They demonstrated that these materials, treated in a proper way, allowed for selective sorption toward nitrogen and oxygen. A great commercial interest arose from the possibility to use these materials for selective adsorption based on small differences in the size of gaseous molecules. Moreover, there was interest in their potential use as catalysts. In the beginning, the oil industry did not accept the idea to use them as catalysts for cracking (break down of long hydrocarbon molecules into gasoline and other useful products). In fact, they thought that these materials were not suited for cracking reactions owing to the small size of their pores. The use of zeolites in this field began thanks to Breck and co-workers, who demonstrated that rare earth-containing zeolites showed cracking activity [41,42]. Many studies aimed at obtaining porous silica materials with pore sizes greater than zeolitic materials, expanding the pore size from the micropore to mesopore region, in order to satisfy the increasing demands of industrial applications and of base research. The main applications concerned the separation of heavy metal ions, the separation and selective adsorption of large organic molecules from wastewater, the formation of a supramolecular assembly of molecular arrays, and the encapsulation of metal complexes in the frameworks [43-45]. In 1992, researchers at Mobil Oil Corporation discovered a new family of silicate/aluminosilicate mesoporous molecular sieves with exceptionally large and uniform pore structures denominated M41S [45], and then produced at Mobil Corporation Laboratories [46]. The discovery resulted in a worldwide resurgence in this area [47]. These new materials showed a pore order organizations similar to zeolites, but they had pore sizes larger than zeolites. These peculiar properties allowed new opportunities to use these materials for applications in catalysis, chemical separation, and adsorption [48]. The synthesis of this family of mesoporous materials is based on the combination of two major sciences, sol-gel science, and surfactant (templating) science. The template agent used is no longer a single, solvated organic molecule or metal ion, but rather a self-assembled surfactant molecular array [48,49]. Figure 2 shows the different structures of the M41S family. 


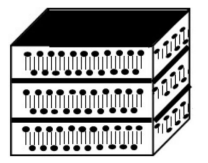

MCM-50

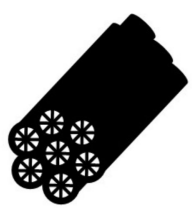

MCM-41

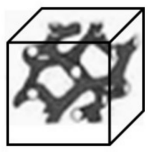

MCM-48

Figure 2. Schematic diagram of the M41S materials, MCM-50 (layered), MCM-41 (hexagonal), and MCM-48 (cubic). MCM stands for Mobil Composition of Matter.

Lamellar (MCM-50), hexagonal (MCM-41), and cubic (MCM-48) phases were obtained [50]. Among them, MCM-41 represents the most thermally stable member and the easiest to produce. It is characterized by highly regular arrays of uniform-sized channels whose diameters are in the range of 15-100 $\AA$. This peculiar organization depends on the kind of templates used, the addition of auxiliary organic compounds, and the reaction parameters [51,52]. The synthesis of these ordered mesoporous materials, as highlighted before, is based on the use of a templating agent, which drives the formation of the structure. It is an organic species, which self-organizes into a crystalline lattice that functions as a central structure where a material, often inorganic, nucleates and grows [53]. After the removal of the templating structure, its geometric characteristics are replicated in the structure of the inorganic materials [54]. In Figure 3, the mechanism of formation of a mesophase proposed by the scientists of Mobil Oil Company is reported (way I). Anionic silicate species and surfactant molecules act synergistically, leading to a hexagonal, lamellar, or cubic structure. In particular, the formation of a hexagonal mesophase should happen in stage two. In the first one, the formation of a hexagonal surfactant array takes place, while in the second one, the adsorption of silicate species onto the preformed external surfaces of hexagonal mesophase occurs [51,52].

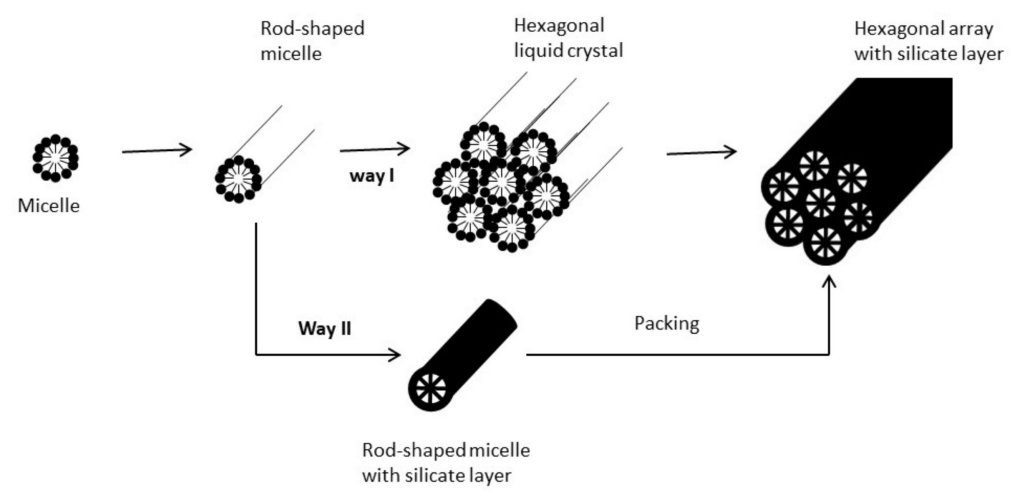

Figure 3. Schematic model of the liquid crystal templating mechanism via two possible pathways.

In the literature, other hypotheses to explain the mesophase formation were made. Chen et al. [55] studied the mechanism by in situ $14 \mathrm{~N}$ nuclear magnetic resonance (NMR) spectroscopy. They hypothesized the formation of two or three monolayers of silica on the outer surfaces of the micelles, which then self-organize into a proper way to form the final hexagonal packing mesoporous MCM-41 (Figure 3, way II). Moreover, they specified that, in order to have hexagonal MCM-41 using tetraethylorthosilicate as a silica source, the concentration of the template should be equal to or higher than the critical micelle concentration. Monnier et al. [56] proposed another mechanism for the formation of the mesophase. They hypothesized that, in the first stage, the surfactant was present in the lamellar phase, which should be then transformed in the hexagonal phase owing to the silicate network condensation and growth (see Figure 4a). Steel et al. [57] proposed yet another mechanism of formation. They hypothesized that, only after the introduction of the silicate source into the reaction medium, the surfactant molecules self-organize to form the hexagonal mesophase. More specifically, the silicate structure initially is ordered into layers between which the micelles of the embryonal 
hexagonal mesophases are sandwiched, then the presence of the silicate results in the layers wrinkling, closing together, and growing into hexagonal channels (see Figure $4 \mathrm{~b}$ ).

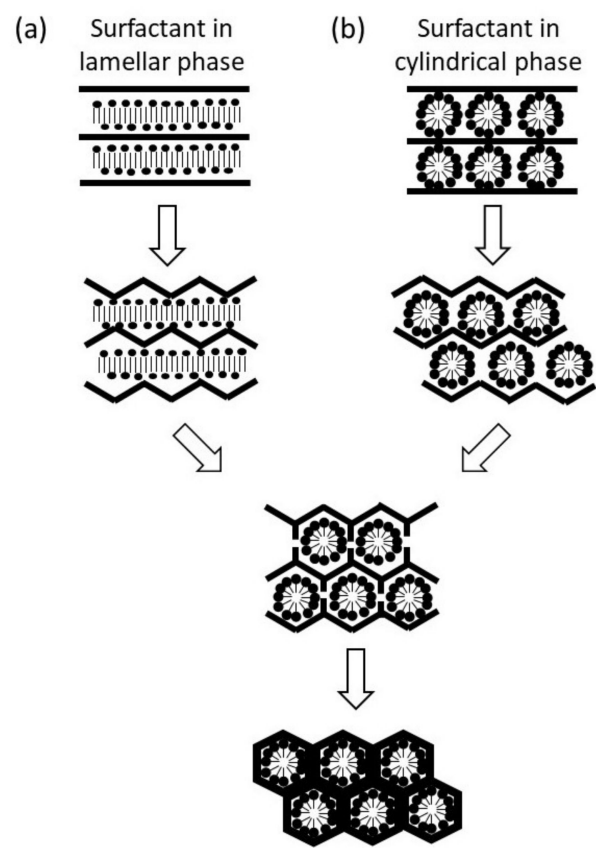

Figure 4. Schematic diagrams of the formation mechanism of MCM-41; (a) the proposed transformation mechanism by Monnier et al. [56] and (b) the formation mechanism proposed by Steel et al. [57].

Mesoporous silica materials are synthetized using a surfactant as a structure directing agent. The obtained silica structure depends on the phase behavior of the surfactant molecules (Figure 5), who self-assemble in a concentration-dependent manner [58]. At low concentrations, the surfactants energetically exist as monomolecules. With increasing concentration, they combine to form micelles to increase the system entropy [59]. There is a concentration of surfactant above which the formation of the micelles occurs. This concentration threshold is named critical micelle concentration (CMC). [60].

\begin{tabular}{|c|c|c|c|c|}
\hline Surfactant & Micelles & Hexagonal & Cubic & Lamellar \\
\hline 0 & & & \\
\hline
\end{tabular}

Figure 5. Surfactant phases as a function of its concentration. CMC, critical micelle concentration.

The CMC value depends on different parameters such as the nature of the surfactant (length of the hydrophobic carbon chain, hydrophilic head group, and counter ion in the case of ionic surfactants), $\mathrm{pH}$, temperature, ionic strength, solvent, and other additives (i.e., organic compounds). In particular, the CMC value decreases with the increase of the surfactant chain length. This depends on the reduction of free energy connected to the micellisation process, which is more pronounced for longer carbon chains. Moreover, increasing the ionic strength in the solution and increasing the valence of the counter ions allow for a further reduction of the CMC. A comparison between ionic and nonionic surfactants show that the former present a lower CMC value [61]. The formation of cylindrical micelles as well as the hexagonal mesophases occurs preferentially in the following conditions: high 
surfactant concentration, high $\mathrm{pH}$, low temperature, and low degree of silicate polymerization [59]. To modulate the pore size in MCM-41 materials, it is possible to change the hydrophobic alkyl chain length of the surfactants or to use auxiliary organic compounds such as trimethylbenzene, which alters the aggregation number and diameter of the micelles. In fact, the auxiliary organic compound solubilizes inside the hydrophobic regions of the micelles, causing an increase in the micelle diameter, which leads to an increase in the pore size of the final product.

For its high thermal stability and easy synthesis, MCM-41 was firstly used for enzyme immobilization. However, the small size of the pores $(2-10 \mathrm{~nm})$ allowed only small enzymes to enter the pores. Trypsin, papain, and cytochrome c were readily adsorbed inside MCM-41 type materials $[62,63]$.

Since the discovery of mesoporous ordered silica materials by Mobil Oil Company, the scientific community has addressed a great interest toward the understanding and improvement in the synthesis of ordered mesoporous materials. The attention was focused on how to modulate the pore size, the pore morphology, and their distribution to obtain the mesoporous structures suitable for different kind of applications, such as adsorption, separation, catalysis, and optical devices. In particular, in 1998, another type of hexagonal array of pores was produced, named Santa Barbara Amorphous no 15 (SBA-15). It had a larger pore size, in the range between 5 and $30 \mathrm{~nm}$, expanding the use of mesoporous materials in other fields of application [64]. The templating agent used was an amphiphilic triblock copolymers in strong acidic media [65]. Moreover, SBA-15 showed high thermal, mechanical, and chemical stability, making it a proper choice for use as a catalyst. These new silicate materials possess extremely high surface areas and narrow pore size distributions $[66,67]$. Thanks to their large pore size, they were used to host bulky enzyme molecules, such as penicillin G acylase [68] and lipase [69].

Another kind of mesoporous materials with a large pore size is the mesoporous cellular foams (MCF). The MCF materials are synthesized with a similar protocol to that of SBA-15, but with oil-in-water microemulsions as templates [70]. MCFs consist of interconnecting cage-like pores with sizes ranging from $20 \mathrm{~nm}$ to $40 \mathrm{~nm}$, and pore interconnection widths ranging from $8 \mathrm{~nm}$ to $25 \mathrm{~nm}$. Another important family of extra-large pore ordered mesoporous silica materials is that named FDU-12. It has pore size up to $20-30 \mathrm{~nm}$ and a three-dimensional pore connectivity [71]. These peculiarities allow for host in the pores big macromolecules, such as large enzymes, avoiding both pore blocking and mass transfer limitations [72]. In fact, Fan et al. [73] found that the cubic structure of FDU-12 displayed better performance than the 2D structure of SBA-15 in terms of pore blockage. The larger pore size of this kind of material allows efficient mass transfer of the enzyme within the porous network.

There are a number of reports on the preparation of mesoporous silica nanoparticles (MSNPs) using non-surfactant templates, such as tartaric acid, glucose, maltose, kanemite [74], and boron oxide [75]. The size of non-surfactant-templated MSNPs can be varied in a broad range without the loss of monodispersity. Using these template, materials were produced that had high surface areas of $\sim 1000 \mathrm{~m}^{2} \mathrm{~g}^{-1}$, pore volumes as large as $\sim 1.0 \mathrm{~cm}^{3} \mathrm{~g}^{-1}$, and narrow pore size distributions. These kinds of template agents are environmentally friendly and have different additional advantages, such as low cost and easy removal. They allow for mild synthesis conditions, but the pore size is usually less than $4 \mathrm{~nm}$, owing to the small size of the templating molecules [76]. Zhe Gao and Ilya Zharov [77] described a one-pot procedure for the synthesis of novel MSNPs with $200 \mathrm{~nm}$ diameter and with large interconnected mesopores tuneable in the 6-13 nm range using an environmental friendly non-surfactant pore-forming agent, tannic acid (TA). They are a rare example of mesoporous silica nanoparticles with uniform size and shape, small dimensions, and large mesopores, making them excellent candidates for biomacromolecule encapsulation. In fact, they were used for the encapsulation of lysozyme and bovine hemoglobin $(\mathrm{BHb})$ [77]; it was found that, for the larger protein $(\mathrm{BHb})$, the adsorption was nearly irreversible. 
From the transmission electron microscopy (TEM) micrograph in Figure 6, the nanoparticles appear highly porous, with higher density in the core of the particles with respect to the periphery, indicating a disordered pore arrangement.

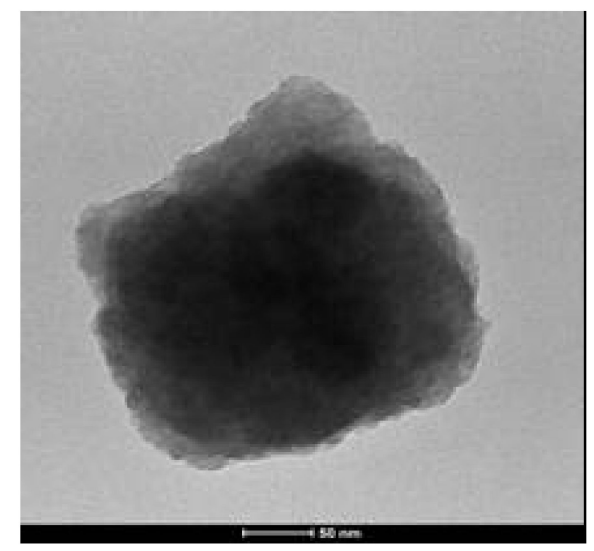

Figure 6. TEM micrograph of a tannic acid template mesoporous silica nanoparticle.

TA is a glucoside polymer of gallic acid with multiple phenolic hydroxyl groups that is found in many plants [78]. One of the advantages of using TA as a porogen is that it is cheap and environmental friendly, as opposed to the expensive and toxic surfactants used in the traditional synthesis of mesoporous materials. TA is an antioxidant whose antimutagenic and anticarcinogenic properties have been extensively investigated [79].

Doo-Sik Moon and Jin-Kyu Lee [80] synthesized mesoporous silica nanoparticles with spherical shape and radial wrinkle structure (wrinkled silica nanoparticles, WSNs). WSNs exhibit a radial open pore structure, in which the pore size is maximum at the extremities, and a hierarchical distribution of pores. A TEM micrograph of this kind of mesostructured silica is shown in Figure 7.

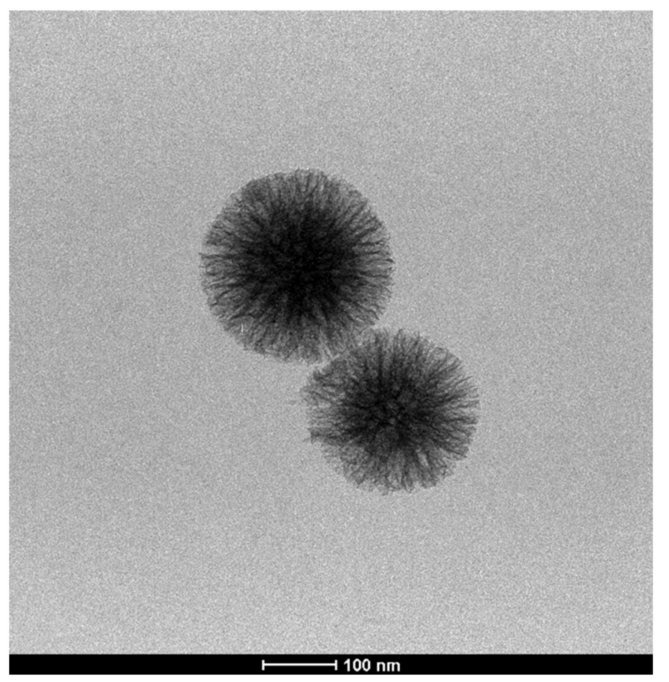

Figure 7. TEM micrograph of wrinkled silica nanoparticles.

The formation of WSNs can be explained by theories of mesoporous silica formation and emulsion rupture-inversion. Their small size in the nanometer range and large surface-to-volume ratio allow their dispersion in various solvents as a colloidal solution, and their radial wrinkle structure, which widens radially outward, is expected to enhance the accessibility of functional materials inside their pores. They have been used as support materials for drug delivery and catalysis [81]. WSNs were used as matrix for the immobilization of lipase, obtaining higher activity in respect to free enzyme [82]. 
The better performance was attributed to the radially aligned mesopores of WSNs, allowing dispersing active catalytic sites on large internal surface and pores.

\subsection{Functionalization}

Functionalization of mesoporous silica materials (MPS) is generally performed to optimize their properties in view of a specific application. These new materials were obtained through functionalization with a range of organic ligands or by the incorporation of metals $[83,84]$. The introduction of organic groups (functionalization) in the mesoporous materials allowed for tuning the surface properties, such as alteration of the surface reactivity, protection of the surface from chemical attack, hydrophobization to preclude water attack, and modification of the bulk properties. These materials have been of great interest in different application fields such as catalysis, adsorption, chromatography, nanotechnology, metal ion extraction, and imprinting for molecular recognition $[85,86]$. Mesoporous silica functionalized with thiol groups on the pore surface presented a high adsorption efficiency for heavy metals such as $\mathrm{Hg}, \mathrm{Ag}$, and $\mathrm{Cd}$ ions $[87,88]$. Mesoporous silica materials grafted with sulfonic acid groups showed a high catalytic activity for selective formation of bulky organic molecules [89]. Various literature reports describe methods for functionalizing the interior pore surfaces of mesoporous solids such as MCM-41 and SBA-15 [90,91]. To obtain these hybrid materials, two different strategies have been followed. The first one, post-synthesis grafting, is carried out after the removal of the surfactant and is based on the use of organosilane compounds. In this case, the functionalization exploits the presence of silanol $(\mathrm{Si}-\mathrm{OH})$ groups of the mesoporous materials. Silylation and esterification are the most common reactions for surface modification [92,93]. To ensure an efficient functionalization, the polymerization of organosilane must proceed on the surface of the pore walls and not in solution. A great interest was addressed toward functionalization with groups such as carboxylate, thiol, and amine groups, which are suitable for the immobilization of proteins. The advantage connected to this kind of functionalization is that they do not modify the pore ordered structure. A drawback of this approach is that it is not possible to ensure that uniform coverage of the surface has been achieved and that all of the functional groups are attached to the pore wall in a proper way. Moreover, the synthesis of mesoporous hybrid materials is not in a one-pot step. The second approach is based on a one-pot step synthesis. The addition of a trialkoxysilane with a suitable functional group is made during the synthesis of mesoporous materials. In this case, a tetraalkoxysilane (siloxane) and organoalkoxysilane precursors with $\mathrm{Si}-\mathrm{C}$ bonds are used, which are involved in the co-condensation through a sol-gel process. Siloxane precursors build up the main framework of the mesoporous materials. Organoalkoxysilane precursors are incorporated in the silica framework and provide functional groups on its surface. This method allows for obtaining both a homogeneous distribution of the functional group on the surface and a high loading of the functional groups [94]. The drawbacks of this approach could be the modification of the mesoporous structure order owing to the addition of the trialkoxysilane and a greater difficulty for the complete removal of the surfactant. Moreover, it could happen that some functional groups are located into the walls of the material and not on the pore surface. At high concentrations of tetraethoxysilanes, phase separation of the silanes may occur [95].

In conclusion, each of the two methods have certain advantages and some drawbacks and the choice will depend on the intended purpose. If a uniform surface coverage with organic groups is desired in a single step, the direct functionalization method may be the first choice. Moreover, it also provides better control over the number of organic groups incorporated in the structure. However, products obtained by post-synthesis grafting are often structurally better defined and hydrolytically more stable. Although pore size can be controlled to some extent by both methods, it is more easily achieved by grafting. Furthermore, functionalization of mesoporous silica must be finely tuned as it can give disadvantages such as pore blocking.

The materials described so far, comprising functionalized and non-functionalized silica mesostructures, are of widespread use as supports in catalysis [96]. Mesoporous silicate materials 
represent a broad platform in the enzymatic immobilization field, owing to their high surface areas and pore volume. These properties allow for high loading of an enzyme that can be hosted in a proper way. The porous structure promotes the stabilization of the enzyme owing to a rigidification of its conformation induced by the interactions with the pore walls. The micro-environment inside the pores can protect the enzyme against adverse environmental conditions, such as high temperatures, extreme $\mathrm{pH}$, and the presence of bubbles or inhibitors. Moreover, silica materials have high chemical, thermal, biological, and mechanical stability and an easy surface functionalization, allowing for hosting a specific enzyme.

\section{Enzymatic Hydrolysis of Cellulose}

\subsection{Lignocellulosic Biomass}

Lignocellulosic biomass is the most abundant, cheap, and renewable source for chemicals and fuels. Fossil fuel depletion and environment degradation have shifted the focus of energy production toward the use of biomass [97]. In this context, the concept of biorefinery has taken root [98].

The use of biomass for biofuel production is favorable for both environmental concerns and geopolitics. Biomass can contribute to attenuate climate changes, as it is $\mathrm{CO}_{2}$ neutral; that is, the carbon dioxide emitted during biofuel combustion is that fixed by the plant during its growth. So, the $\mathrm{CO}_{2}$ released during ethanol burning is offset by the $\mathrm{CO}_{2}$ captured when the feedstock crops are grown to produce ethanol. This differs from fossil fuels, where the $\mathrm{CO}_{2}$ was removed from the atmosphere ages ago. Ethanol has higher oxygen content in respect to fossil fuels, producing cleaner combustion in terms of soot, CO, and unburned hydrocarbons [99]. Furthermore, biomass is available worldwide, diminishing our dependence on oil-producing countries, which are often politically unstable.

Plant cell walls are mainly composed of lignocellulosic material. It is a hetero-structure with a complex architecture consisting of three polymers, cellulose, hemicellulose, and lignin.

Cellulose is the most abundant constituent $(40-50 \%)$ and confers structural support to plant cells. It is a linear homopolymer of $\beta$-D-glucopyranoside moieties linked together by $\beta-(1,4)$ bonds. Its repeating unit is the disaccharide cellobiose, formed by consecutive glucose molecules rotated $180^{\circ}$ [100]. The cellulose chains are organized in microfibrils of 20-300 units, held together by hydrogen bonds and Van der Waals forces. This very compact crystal structure is the cause of the recalcitrance of cellulose to enzymatic degradation. In fact, the cellulose chains are tightly packed together and do not allow penetration not only by enzymes, but also by small molecules such as water. However, the crystalline regions are interspersed with amorphous regions (5-20\%), which are much more prone to enzymatic hydrolysis [101]. Cellulose fibrils have two different ending groups: at one end, a non-reducing sugar moiety is found, and at the other end, a reducing one is found.

The second major component of plant cell is hemicellulose $(20-40 \%)$. It is a branched hetero-polymer of both hexoses (glucose, mannose, and galactose) and pentoses (xylose, rhamnose, and arabinose) of amorphous nature that bundles together the microfibrils forming the cellulose fibers. Hemicellulose has a lower molecular weight in respect to cellulose, and its amorphous and branched structure makes it more susceptible to enzymatic hydrolysis [102].

The third component of a plant cell is lignin. It is a phenolic hetero-polymer of complex composition and branched structure that acts as a binder for cellulose fibres. It gives structural support to plant cells and is responsible for their resistance to microbial attack. In fact, lignin is considered a major impediment to enzymatic hydrolysis, not only for being a physical barrier, but also for its nonspecific adsorption of cellulolytic enzymes on its sticky surface [103,104].

The complex structure of lignocellolosic biomass, with its cellulose fibers embedded in an amorphous matrix of hemicellulose and lignin, gives the plants their natural recalcitrance to biological degradation, so that biomass pretreatment is a crucial step to increase cellulose accessibility and improve the hydrolysis yield. A set of pretreatment methods are available, including chemical and physical methods [105], which have the purpose of destructuring the lignocellulosic biomass and 
disrupting the crystalline structure of cellulose, making it more accessible. A schematic illustration of lignocellulosic biomass structure before and after the pretreatment process is illustrated in Figure 8.

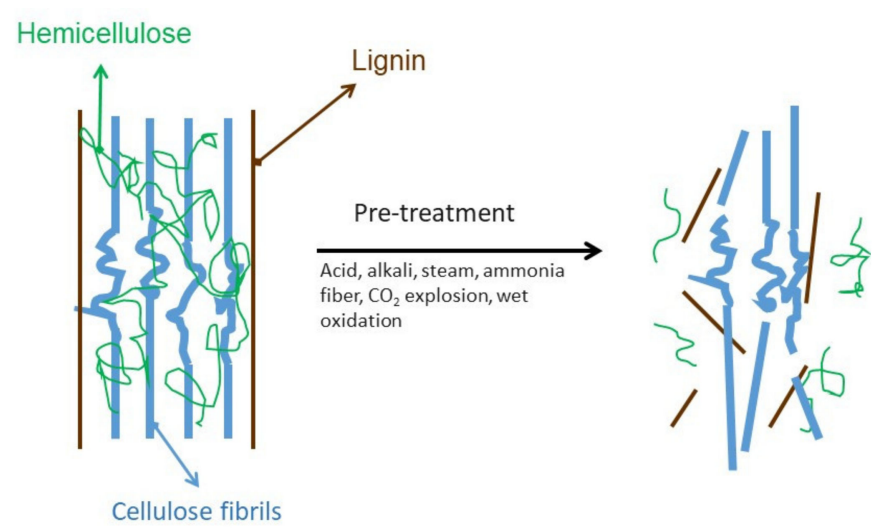

Figure 8. Biomass structure before and after pretreatment.

\subsection{Cellulolytic Enzymes}

The enzymatic hydrolysis of cellulose is carried out by a set of enzymes called cellulases. In nature, the hydrolysis of cellulose is mediated by three main types of cellulase: 1.4- $\beta$-endoglucanases EGs (EC 3.2.1.4), cellobiohydrolases (or 1.4- $\beta$-exoglucanases) CBHs (EC 3.2.1.91), and $\beta$-glucosidases or cellobiase BGs (EC 3.2.1.21). Cellulases belong to glycosyl hydrolases (GH, EC 3.2.1), a widespread group of enzymes classified into 155 families based on their amino acid sequence and their crystal structure [106].

Cellulases hydrolyze the $\beta-1,4$ links of cellulose and hemicellulose chains. The complete set of cellulases works synergistically to convert crystalline cellulose to glucose and the synergy is applied on several levels. Endo- and exoglucanases act on insoluble cellulose (primary hydrolysis), whereas $\beta$-glucosidases hydrolyze the cellodextrins released thereof (secondary hydrolysis). The primary hydrolysis step occurs on the solid substrate and is the rate-limiting step of cellulose hydrolysis.

Endoglucanases are active on amorphous regions of cellulose, randomly cutting internal linkages, creating new reducing and non-reducing end chains [107] and rapidly decreasing the degree of polymerization of cellulose. The cleavage of the $\beta-1.4$ links by these enzymes occurs on the surface of insoluble cellulose and releases soluble cellodextrins with a degree of polymerization (DP) up to 6 [108].

Cellobiohydrolases (exoglucanases) act in a processive manner on the reducing and non-reducing ends of the cellulose chains. The free ends are both those possessed by cellulose fibers before the attack of EGs and those created by the action of EGs. The main product released is cellobiose [109]. CHBs, unlike EGs, are able to act on the crystalline region of cellulose. Two immunologically distinct $\mathrm{CBH}$ have been identified, CBHI and CBHII, attacking the reducing and non-reducing ends of cellulose chains, respectively [110]. There is a high degree of synergy between exo- and endoglucanase, crucial for an efficient hydrolysis of crystalline cellulose.

Finally, $\beta$-glucosidase hydrolyses soluble cellobiose and ciclodextrins with a DP up to six to glucose. Its activity is negligible on solid cellulose. BG is considered a bottleneck of the whole cellulose degradation process by reducing cellobiose accumulation. Cellobiose acts as inhibitor for both endo and exo-glucanase activities, so it is crucial to have a high activity of BG in the enzymatic cocktail to maintain a high hydrolysis rate [111].

Figure 9 illustrates the mechanism of action of the three enzymes. 


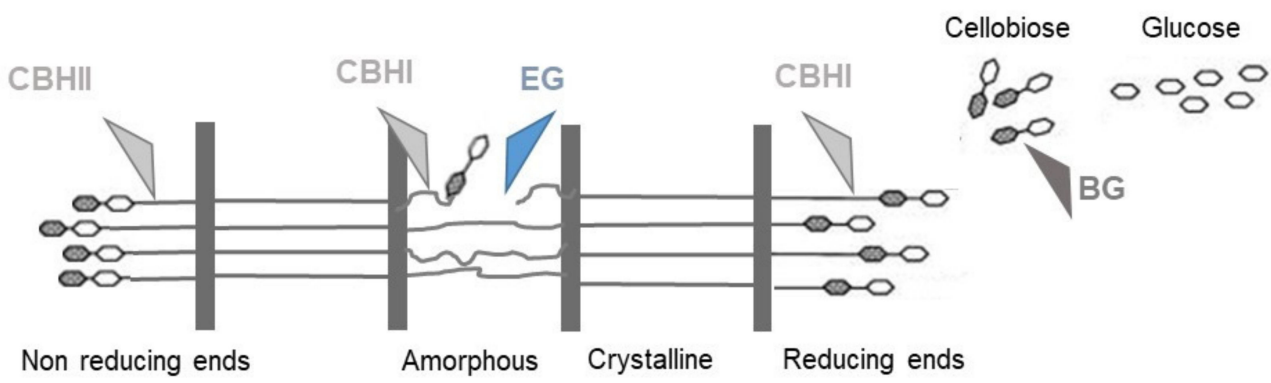

Figure 9. Mechanism of action of cellulase on cellulose. $\mathrm{CBH}$, cellobiohydrolase; EG, endoglucanase; BG, $\beta$-glucosidase.

The cellulose chains are degraded to glucose through sequential and synergistic actions of the three enzymes. Irvin et al. [112] highlighted the synergy demonstrating that cellulases acting together have greatly enhanced hydrolytic activity compared with the single components.

Two independently folding units, with independent structures and functions, called modules or domains, compose most cellulases, except for BG. The carbohydrate/cellulose binding domain (CBD) is linked at the $\mathrm{C}$-terminal with the $\mathrm{N}$ - terminal of the catalytic domain (CD) through a short poly-linker region. The linker is a short amino acid sequence (6-95 residues) rich in proline and hydroxyamino acids [4] and functions as a flexible arm that ensures the functional independence of the two domains [113]. This modular structure allows the enzyme to work on an insoluble substrate and to diffuse two-dimensionally on the surface of the cellulose, "peeling" it. The CBD sequence is made of about 35 amino acids and is rich in serine and threonine [114]. The aromatic residues are believed to pack on the glucose rings, giving stability to the enzyme-substrate complex. The CBD interacts with crystalline cellulose through their hydrophobic flat surface formed by three conserved aromatic amino acid residues. This flat surface overlaps with the flat surface formed by the pyranose rings of cellulose [115]. Polar residues that form hydrogen bonds stabilize this interaction [116]. The role of the CBD is to bind the enzyme to the surface of cellulose, keeping the CD in close and prolonged association with the substrate.

The active site of the three cellulases (EG, CBH, and BG) has a distinct three-dimensional arrangement. The active site of most endoglucanases has a cleft shape that can bind cellulose surface chains in the amorphous regions. Exoglucanases have a tunnel-shaped active site formed by two surface loops. This shape allows retaining a single chain end and preventing it from re-adhering to the cellulose crystal [117]. $\beta$-glucosidases do not have a CBD because they act on soluble cellodextins and their active site is pocket-shaped to bind a non-reducing glucose unit and clip it off from cellobiose or cellodextrins. Figure 10 shows the structure of a complexed $\beta$-glucosidase and the complexed catalytic domain of a cellobiohydrolase and an endoglucanase.
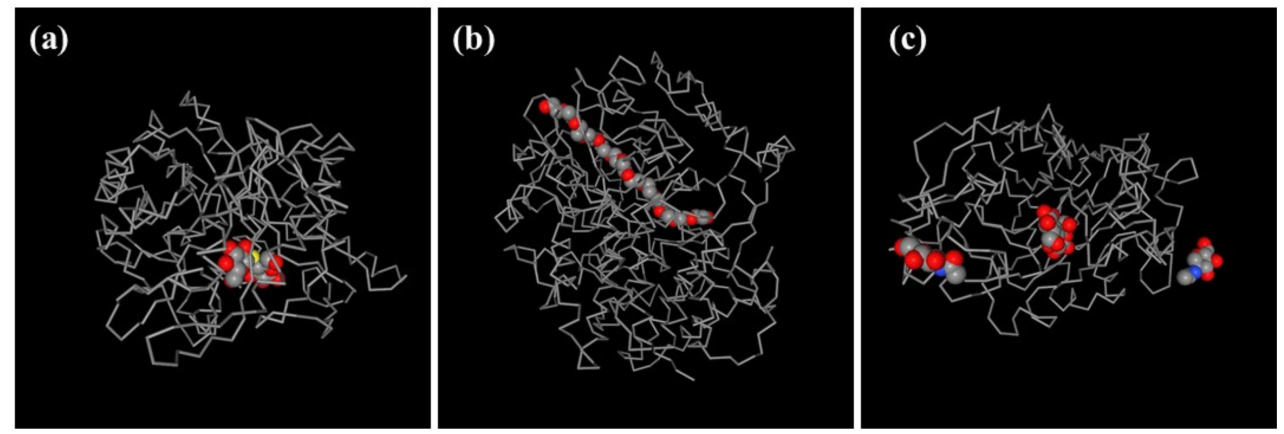

Figure 10. Backbone structure of (a) $\beta$-glucosidase B from Paenibacillus polymyxa complexed with thiocellobiose, (b) the catalytic domain of exoglucanase CelS from Clostridium thermocellum complexed with polyethylene glycol (PEG), and (c) the catalytic domain of endoglucanase I from Fusarium oxysporum complexed with cellobiose (Protein Data Bank). 
Cellulases are produced by fungi, bacteria, protozoans, plants, and animals. Currently, most industrial cellulases are produced by aerobic fungi. These engineered strains are able to produce high amounts of cellulase with high specific activity. Aerobic fungi secrete a set of individual cellulases. Most anaerobic microorganism produce multi-enzyme complexes called cellulosome, in which the enzymes are attached to a scaffolding protein possessing a CBD. These cellulosomes are very active in degrading cellulose [118].

One of the most studied fungi for cellulolytic enzyme production is Trichoderma reesi. The cellulase produced by this species, however, lacks sufficient BG activity [119]. BG is essential for efficient hydrolysis of the biomass, as it relieves the inhibition by cellobiose on the other two cellulolytic enzymes. BG is highly dependent on EG and $\mathrm{CBH}$, as they release the soluble substrate that it hydrolyses. On the other hand, EG and CBH are highly dependent on BG to maintain high hydrolysis rates and yields. A balanced enzyme cocktail is then crucial for an efficient hydrolysis of biomass.

The immobilization of cellulase can be unpractical, with the main issue being the insolubility of cellulose. Actually, CBH and EG must adsorb on the cellulose surface to perform their catalytic action, and this may be difficult if they are in immobilized form. This is the first issue that needs to be addressed when immobilizing cellulases. Furthermore, EG and CBH have a high affinity for cellulose and can be recovered and recycled by adsorption onto fresh substrate [120]. However, BG does not adsorb on cellulose, and thus cannot be recovered in this way [121]. The immobilization of $\beta$-glucosidase can be practical, as its substrate is water-soluble.

\section{Immobilization of BG on Mesostructured Silica}

Immobilized $\beta$-glucosidase can be used to supplement cellulases that possess low $\beta$-glucosidase activity [122]. In fact, it was demonstrated that the supplementation of commercial cellulases with $\beta$-glucosidase increased the rate and yield of glucose production [123]. Furthermore, $\beta$-glucosidase finds applications in many biotechnological fields. BGs can be found ubiquitously in plants, fungi, animals, and bacteria. Their physiological roles are diverse, as they are capable of hydrolyzing various $\beta$-linked diglucosides and aryl- $\beta$-glucosides. In cellulolytic microorganisms, they are involved in cellulose hydrolysis, but in other organisms, they play other roles. For example, in plants, BGs catalyze $\beta$-glucan synthesis, provide defense against microbial attack through the release of cumarin, and are implicated in a variety of metabolic events [124]. Thanks to their versatility, immobilized BG can find applications in several biotechnological processes, such as the release of aromatic residues in the flavor industry and the synthesis of oligosaccharides and glycosides in the pharmaceutical industry [125].

The first report on immobilization of BG on mesostructured silica was in 2010 [126]. Here, $\beta$-glucosidase from almonds was immobilized by physical adsorption on SBA-15. The relative size of the mesopores $(7.5 \mathrm{~nm})$ and the enzyme $(6.6 \mathrm{~nm}$ for the dimer) was suited for high adsorption capacity. The immobilized enzyme retained $95 \%$ of its activity. The activity was evaluated in the hydrolysis of the artificial substrate 4-nitrophenyl- $\beta$-D-glucopyranoside (p-NPG). The optimum immobilization and reaction $\mathrm{pH}$ was experimentally determined to be 3.5. The loading capacity at that $\mathrm{pH}$ value was $430 \mathrm{mg}$ per gram of support. It was hypothesized that the driving force for the immobilization process was the electrostatic interaction between the positively charged enzyme (isoelectric point pI 5.5) and the negatively charged silica surface (pI about 2). For the enzyme immobilized at $\mathrm{pH} 5.5$, leaching was detected during the reaction, owing to weaker enzyme-support interactions. In a later work [127], the same research team demonstrated that the maximum difference in the zeta potential between the enzyme and the support was at $\mathrm{pH} 3.5$, endorsing the hypothesis of electrostatic interaction as the driving force of the adsorption process. They also showed that most of the enzyme was located at the pore mouth, blocking the entrance. In this way, the access of the substrate molecules to the active site of the enzyme was facilitated, as the substrate did not need to diffuse inside the pores of the support. In this work, the authors performed the adsorption and the reaction in a fixed bed column. At the optimal $\mathrm{pH}$, the adsorbed amount was higher than the one obtained for the adsorption in batch 
experiments, up to 3.5 times. The adsorption equilibrium time was shorter ( $4 \mathrm{~h}$ vs. about $8 \mathrm{~h}$ ). This was attributed to the higher pressure of $300-500 \mathrm{kPa}$, owing to a pressure drop, in the fixed bed column in respect to batch experiment performed at ambient pressure. In the washing step, the amount of enzyme leached from the support was only $7 \%$, suggesting a strong enzyme-support interaction. The immobilized enzyme reached $100 \%$ p-NPG hydrolysis yield after ten minutes, maintaining this activity level for $12 \mathrm{~h}$. Contextually, Wei et al. [128] encapsulated a cellobiase- $\beta$-glucosidase Novozyme 188-in non-surfactant template sol-gel mesoporous silica, using fructose as templating agent. The enzyme molecules, added to the hydrolyzed silica precursor sol, were trapped inside the host matrix by gelation. They synthesized a set of silica materials by varying the weight percentage of fructose: $0 \%, 30 \%, 50 \%$, and $70 \%$. The pore size increased with increasing fructose content shifting from the microporous for the $0 \%$ sample $(1.5 \mathrm{~nm})$ to the mesoporous for the $30 \%$ sample $(2.0-2.5 \mathrm{~nm})$ and the $50 \%$ and $70 \%$ samples $(3.0-3.5 \mathrm{~nm})$. The increase in fructose content also led to an increase in surface area, suggesting a larger concentration of open pores. Fructose was chosen as porogen agent as it is the most water-soluble sugar and could be extracted from the silicate structure by a simple water extraction procedure. The activity and the catalytic constant $K_{M}$ and $V_{\max }$ were determined for the four samples in the hydrolysis of cellobiose at $\mathrm{pH}$. The samples with higher template content $\left(50 \%\right.$ and $70 \%$ ) showed an activity of about $82.8 \%$ and $80.0 \%$ of the free cellobiase. The $V_{\max }$ values were $70.6 \%$ and $68.3 \%$ of that of free cellobiase. The $50 \%$ biocatalyst showed activity and $V_{\max }$ values closer to those of the free enzyme than the $70 \%$ biocatalyst. The activity and $V_{\max }$ of $0 \%$ and $30 \%$ were markedly worse. This was attributed to the bigger pores and higher concentration of open pore channels in the $50 \%$ and $70 \%$ samples, which favored accessibility to the enzyme active site. Concerning the $\mathrm{K}_{\mathrm{M}}$ values, for the $0 \%$ and 30\% samples, there was an unusual decrease that is not explained. All immobilized biocatalysts retained their activities up to nine reuses, indicating a tight and efficient encapsulation and a good enzyme stability. The biocatalysts were used in a two-step hydrolysis of pre-treated biomass [129]. Two pretreatments were used, with $2.5 \% \mathrm{FeCl}_{3}$ solution and $0.5 \mathrm{M}$ oxalic acid solution. The best hydrolysis efficiencies obtained were $74 \%$ for $\mathrm{FeCl}_{3}$ pre-treated biomass and $81 \%$ for oxalic acid pre-treated biomass. The reusability of the biocatalysts was tested. They retained their activity for up to ten reuses. It was argued that, with the molecular diameter of cellulase $(5 \mathrm{~nm})$ being bigger than the pore size of the silica matrix, the encapsulated enzyme is unable to get out.

Later, Guan et al. [130] immobilized $\beta$-glucosidase from almonds on aminopropyl-functionalized ethane-bridged bifunctional mesoporous organosilicas (APEPMOs), as reported in Scheme 1, with post-synthesis expansion of pores by means of $\mathrm{N}, \mathrm{N}$-dimethyldecylamine.

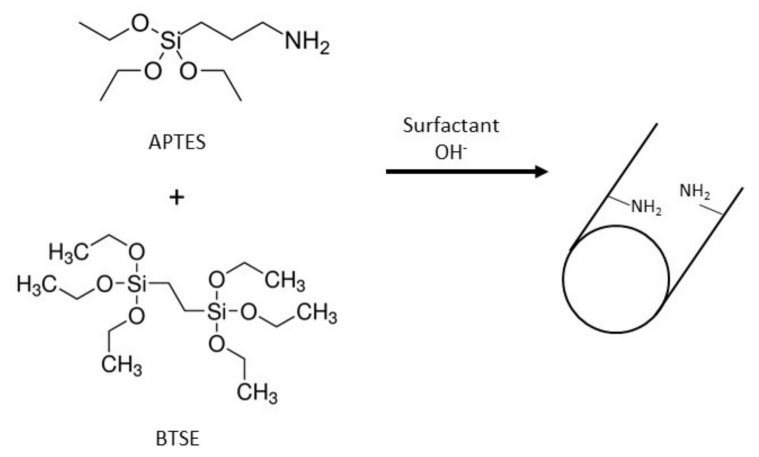

Scheme 1. Synthesis of aminopropyl-functionalized ethane-bridged bifunctional mesoporous organosilicas (APEPMOs) starting from aminopropyltriethoxysilane (APTES) and 1,2-bis(triethoxysilyl)ethane (BTSE).

In fact, it was shown that functionalization of mesoporous silica generally gives higher retention of the enzyme molecules than non-functionalized one [131]. However, functionalization of mesoporous silica often gives disadvantages such as pore blocking; the use of bifunctional periodic organosilanes can attenuate these problems. The synthesised materials possessed bottleneck pores with large spherical 
pores connected by narrower necks. The pore size distribution was centred at $7.4 \mathrm{~nm}$. Immobilization of $\beta$-glucosidase was carried out at $\mathrm{pH} 3.5$ and its activity was measured against p-NPG. The enzyme loading was $120 \mathrm{mg}$ per gram of support for an adsorption time of $18 \mathrm{~h}$. The amount of enzyme leaching during the washing steps was only $5 \%$, indicating that the enzyme was tightly bound to the support, possibly owing to the presence of organic groups. The immobilized enzyme retained $95.5 \%$ of enzymatic activity and was reused up to 20 times, maintaining more than $75 \%$ relative activity. This was attributed to the strong interaction between the enzyme and the support that prevents leaching and to the matching of pore size $(7.4 \mathrm{~nm})$ and enzyme diameter $(6.7 \mathrm{~nm})$ that protected the enzyme from denaturation. The immobilized enzyme showed higher thermal stability than the free one, possibly owing to an increase in enzyme rigidity related to the immobilization of the enzyme inside the pores. In the same year, Reshmi and Sugunan [132] reported the immobilization by crosslinking of $\beta$-glucosidase from almonds in large mesoporous cellular foam (LMCF) synthesized using the microemulsion templating route. The silica mesoporous foam had a pore size distribution centred at $16.1 \mathrm{~nm}$. The enzyme was first physically adsorbed inside the pores at $\mathrm{pH} 4.8$, where it formed physical aggregates, and then glutaraldehyde (GA) was added to obtain cross-linked enzyme aggregates (CLEAs) of nanometre scale. It was claimed that this approach is simpler than covalent immobilization and more efficient than physical adsorption as it hinders leaching. The enzyme loading was $139 \mathrm{mg} / \mathrm{g}$. The activity, $\mathrm{K}_{\mathrm{M}}$ value, and $\mathrm{V}_{\max }$ value were measured in the hydrolysis of $\mathrm{p}-\mathrm{NPG}$ at $\mathrm{pH}$ 4.8. The retained activity of the immobilized enzyme was $77.4 \%$ of that of the free enzyme. The $\mathrm{K}_{\mathrm{M}}$ value was higher $(8.2 \mathrm{mM}$ vs. $5.9 \mathrm{mM})$, suggesting that the cross-linked network restricted the diffusion of substrate and product to and from the active site of the enzyme. The $V_{\max }$ was slightly smaller $(0.0120$ vs. $0.0135 \mathrm{mM} / \mathrm{min})$, which was attributed to a reduced flexibility of the cross-linked enzymes. CLEAs exhibited a broader tolerance to temperature and $\mathrm{pH}$ than the free enzyme owing to the reduced conformational flexibility of the crosslinking procedure and retained $85 \%$ of activity after ten reuses. The most significant result concerns the storage stability; after 60 days of storage in buffer at $4{ }^{\circ} \mathrm{C}$, CLEAs were fully active, whereas the free enzyme lost more than $85 \%$ of its activity after 10 days of storage. Apparently, crosslinking of $\beta$-glucosidase molecules led to a drastic stabilization of the enzyme during storage.

Ivetić et al. [133] immobilized $\beta$-glucosidase NS22118 from Novozymes Cellulosic Ethanol Enzyme Kit on mesoporous silica synthesized from highly basic sodium silicate solutions. The obtained silica particles consisted of micro-sized aggregates. The porosity was inter-particle. Silica support with average pore size of $29 \mathrm{~nm}$ was chosen, as it maximized adsorption. The enzyme was immobilized by both physical adsorption and covalent binding. Covalent binding was obtained by functionalization of silica with 3-amino-propyltriethoxysilane (APTES) and subsequent activation with GA, according to Scheme 2.

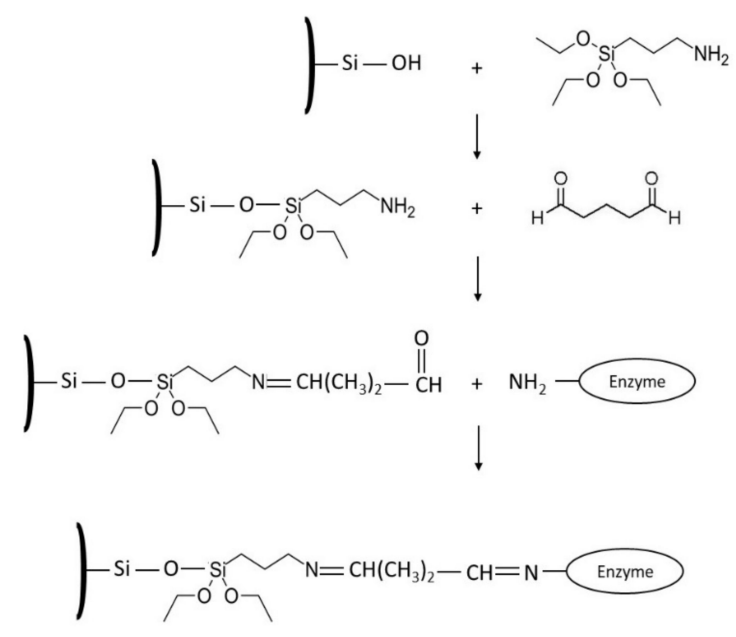

Scheme 2. Functionalization of silica with APTES and activation with glutaraldehyde (GA). 
The immobilization yields were $20 \mathrm{mg}$ per gram of support for adsorption and $40 \mathrm{mg}$ per gram of support for covalent immobilization. The activity was measured in the hydrolysis of p-NPG at pH 5.0. The immobilized biocatalysts retained $36.6 \%$ and $74.8 \%$ of activity, respectively. This was explained with a higher affinity of the covalently immobilized enzyme toward the substrate, highlighted by a lower $\mathrm{K}_{\mathrm{M}}$ value (11.06 $\mathrm{mM}$ for covalent immobilization vs. $15.63 \mathrm{mM}$ for adsorption). It is also possible that the spacer arm used in covalent immobilization increased enzyme mobility. For its better performance, the covalently immobilized biocatalyst was chosen for further analysis. Covalent binding did not considerably change the thermal stability of the enzyme, but the $\mathrm{pH}$ stability was extended toward the basic values, up to $\mathrm{pH}$ 8.0. The covalently immobilized $\beta$-glucosidase was used to supplement a cellulose complex (Celluclast $1.5 \mathrm{~L}$ by Novozymes) and its operational stability was determined in the hydrolysis of carboxymethylcellulose (CMC) at $\mathrm{pH}$ 4.7. After ten cycles of use, the biocatalyst retained more than $70 \%$ of its initial activity. The details of immobilized enzyme separation from the reaction mixture are not given.

Chi et al. [134] co-immobilized $\beta$-glucosidase from almonds and glucose isomerase (GI) produced in-house by gene cloning on stellate macroporous silica nanoparticles (MSN). Glucose isomerase converts glucose to fructose. The aim was to realize a biocatalyst for cascade conversion of cellobiose derived from lignocellulosic biomass to glucose to fructose. The co-immobilization of two cascade enzymes allowed the direct transfer of the reagent from one catalytic site to the other, avoiding the necessity to diffuse into the bulk of the reaction mixture (channeling effect). The stellate MSN had a hierarchical porosity with an average pore size distribution of $12.6 \mathrm{~nm}$, suitable for the encapsulation of bulky enzymes. The immobilization was carried out by physical adsorption. A complete immobilization of both enzymes was obtained ( $0.4 \mathrm{mg}$ of GI and $2 \mathrm{mg}$ of BG per $50 \mathrm{mg}$ of SMN). The $\mathrm{pH}$, temperature, and time of reaction were optimized to $7.0,55^{\circ} \mathrm{C}$, and $20 \mathrm{~h}$. The activity of the immobilized enzymes was similar to that of the free ones. The biocatalyst were used in four consecutive cycles of reaction, showing a gradual decrease in activity, which is envisaged to be mitigated through chemical attachment of the enzymes to the support.

Gascón et al. [135] encapsulated $\beta$-glucosidase from Aspegillus niger (Novozym 188) in siliceous mesocellular foam (SMF). The encapsulation was made via an in situ immobilization approach. The conditions of synthesis were optimized to reach a compromise between the development of a mesostructured support and the retention of the enzymatic activity. In fact, the synthesis of siliceous materials involves extreme reaction conditions in terms of $\mathrm{pH}$ and temperature. Here, the optimal $\mathrm{pH}$ was set to 3.5 and temperature was $50{ }^{\circ} \mathrm{C}$. The reaction proceeded for five days. Two micelle expanders were used, with the best one being $\mathrm{m}$-xylene. The activity of the obtained biocatalyst was essayed in the hydrolysis of p-NPG. The support characterization was performed after the complete removal of all organic species extraction with ethanol in drastic conditions. The siliceous support had a cage-window structure with pores of about $9.0 \mathrm{~nm}$ and windows of about $3.6 \mathrm{~nm}$. Hence, the size of the silica cages could accommodate a single enzyme molecule per cavity. The small cage windows prevented the enzyme from leaching, as experimentally detected. It is assumed that the enzyme may act as a template for the formation of the mesoporous structure. In the best case, the enzyme loading was $175 \mathrm{mg}$ per gram of support. The enzyme retained $56 \%$ of its activity and was reusable for at least eight times without loss of activity.

Recently, wrinkled silica nanoparticles (WSNs) with a trimodal hierarchical micro-mesoporous structure were used to immobilize $\beta$-glucosidase from almonds $[136,137]$. WSNs are colloidal particles of 200-250 nm, whose internal morphology is composed by silica fibres or wrinkles coming out from the centre of the particles. The wrinkles spread uniformly in all directions, forming central-radial pores, which widen radially outward. The pore size distribution indicates the presence of mesopores in the range 5-50 nm, which corresponds to inter-wrinkled distances having a mean value of $12.2 \mathrm{~nm}$. A second distribution in the range of $2-4 \mathrm{~nm}$ is observed, suggesting a mesoporous structure in addition to wrinkles. There is a third pore size distribution centred at 1-2 nm. Hierarchical micro/mesoporous structures enhance diffusion of small molecules (i.e., glucose and cellobiose). The immobilization was 
carried out by physical adsorption at $\mathrm{pH}$ 5.0. The enzyme loading was $150 \mathrm{mg}$ of enzyme for a gram of matrix. The kinetic constants $\mathrm{K}_{\mathrm{M}}$ and $\mathrm{V}_{\max }$ were determined in the hydrolysis of cellobiose at $\mathrm{pH} 5.0$ and $50{ }^{\circ} \mathrm{C}$. The kinetic parameters were $\mathrm{K}_{\mathrm{M}}=5.4 \mathrm{mM}$ and $4.3 \mathrm{mM}$ and $\mathrm{V}_{\max }=43 \mu \mathrm{mol} / \mathrm{min} \cdot \mathrm{mg}$ and $41 \mu \mathrm{mol} / \mathrm{min} \cdot \mathrm{mg}$ for free and immobilized BG, respectively. The decrease in $\mathrm{K}_{\mathrm{M}}$ of the immobilized enzyme was attributed to an enhanced local concentration of the substrate owing to its interaction with the matrix. The biocatalyst was reused five times. There was no decrease in glucose yield in the first three reuses. In the fourth, the yield reduced to $80 \%$, and to $40 \%$ of its initial value with the fifth reuse. To improve the reusability of BG-WSNs complex, BG was covalently immobilized [138]. The covalent linking was obtained through the bifunctional molecule triethoxysilylpropylisocyanate (TEPI), according to Scheme 3.
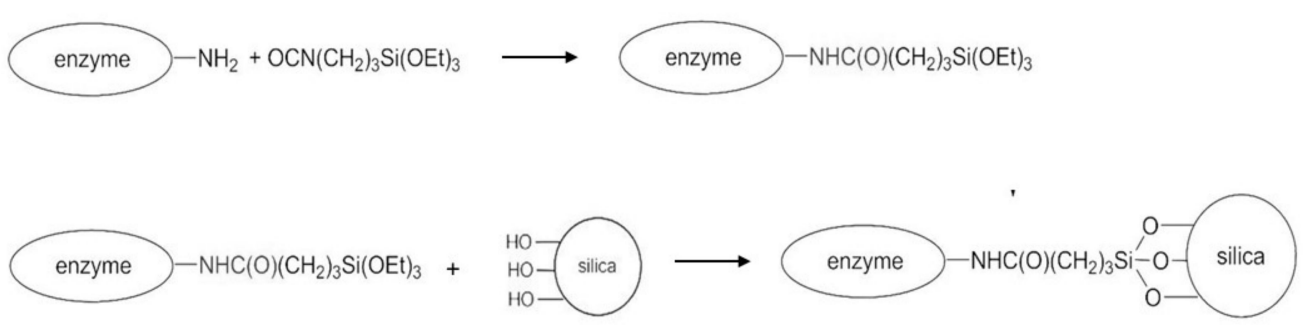

Scheme 3. Covalent linking of BG to silica through the bifunctional molecule triethoxysilylpropylisocyanate (TEPI).

The whole reaction was carried out in anhydrous acetone. In this solvent, the enzyme is insoluble. This should restrict its conformational freedom, and thus preserve its native structure. The amount of the crosslinking agent was optimized. The kinetic constants were determined in the hydrolysis of cellobiose at $\mathrm{pH} 5.0$ and $50{ }^{\circ} \mathrm{C}$. The $\mathrm{K}_{\mathrm{M}}$ value further decreased with respect to the physically adsorbed enzyme to $2.5 \mathrm{mM}$. This is possibly because of the increased enzyme mobility during the reaction for the presence of a flexible arm of suitable length (TEPI). The immobilized enzyme showed increased thermal stability compared with the free one. The operational stability of the covalently immobilized enzyme was effectively increased in respect to the physically adsorbed one, retaining $70 \%$ of its activity after seven reuses.

Finally, $\beta$-glucosidase from almonds was immobilized by physical adsorption on tannic acid template mesoporous silica nanoparticles [139]. Three types of colloidal particles with different porosity and surface features were obtained by varying the amount of the porogen: one is nonporous, the second has mesopores that are too small to host the enzyme, and the third has mesopores large enough to host the enzyme. It was demonstrated that the rough surface of the second kind of nanoparticles allowed the spontaneous formation of a protein corona, preserving most of the secondary structure of the enzyme. The enzyme was located on the surface of the nanoparticles, but was well anchored. This has the advantage of an immobilized enzyme that is readily available for reaction in respect to an enzyme located inside the pores. The kinetic constants were determined in the hydrolysis of cellobiose at $\mathrm{pH} 5.0$ and $50^{\circ} \mathrm{C}$. For the best performing biocatalyst, the $\mathrm{K}_{\mathrm{M}}$ value was only slightly higher than that of the free enzyme $(6.6 \mathrm{mM}$ vs. $5.4 \mathrm{mM})$, while the $V_{\max }$ was about half. The immobilized biocatalyst showed higher thermal stability than the free enzyme and was reusable four times without loss of activity. At the fifth reuse, the activity dropped to $60 \%$, as already observed for BG physically immobilized in WSNs.

A different application of BG immobilization was proposed by Zlateski et al. [140]. They immobilized $\beta$-glucosidase from almonds in siliceous mesocellular foam (MCF) by physical absorption at $\mathrm{pH}$ 7.0, obtaining an enzyme loading of $80 \mathrm{mg}$ per gram of MCF. This $\mathrm{pH}$ value was chosen to obtain a slight positive surface charge on the enzyme $(\mathrm{pI}=7.3)$, so that there is attraction between the protein and the negatively charged silica surface, but not a strong self-repulsion between the protein molecules. The silica matrix had pore size distribution centred at $23 \mathrm{~nm}$ and pore windows of 
$11 \mathrm{~nm}$. They further entrapped the enzyme inside the structure by precipitating additional silica within the channels of MCF, by policondensation of tetraethoxysilane in mild conditions for five days. The aim was to obtain a protective shell for the enzyme that could favor long-term storage stability. The idea was to replace the freezer with the shelves. The silica shell was then dissolved with a fluoride buffer containing $\mathrm{NH}_{4} \mathrm{FHF}$ and $\mathrm{NH}_{4} \mathrm{~F}$ at $\mathrm{pH}$ 4.0. The activity after the enzyme release, measured in the hydrolysis of p-NPG, was comparable to the activity of BG free in solution after five days of storage in the fridge, indicating a very small activity loss due to the entrapment/release procedure. After 15 days of wet storage in the fridge, the free enzyme lost $50 \%$ of its initial activity, while no substantial loss of activity was observed for the entrapped enzyme after release. The entrapped enzyme was also incubated at different temperatures up to $70^{\circ} \mathrm{C}$. After release, the enzyme retained $100 \%$ of its activity for incubation at 50 and $60{ }^{\circ} \mathrm{C}$ and $75 \%$ at $70{ }^{\circ} \mathrm{C}$. This thermal resistance was attributed to the protective effect of the silica shell.

A summary of BG immobilization on mesostructured silica is reported in Table 1.

Table 1. Summary of $\beta$-glucosidase (BG) immobilization on various mesoporous silica materials. CLEA, cross-linked enzyme aggregate; SBA-15, Santa Barbara Amorphous no 15.

\begin{tabular}{|c|c|c|c|c|c|}
\hline Material & $\begin{array}{l}\text { Average Pore Size } \\
\text { (nm) }\end{array}$ & $\begin{array}{c}\text { Immobilization } \\
\text { Technique }\end{array}$ & $\begin{array}{l}\text { Loading } \\
\text { (mg/g) }\end{array}$ & $\begin{array}{l}\text { Residual Activity } \\
(\%)\end{array}$ & Ref. \\
\hline SBA-15 & 7.5 & adsorption & 430 & 95 & {$[126,127]$} \\
\hline bifunctional organosilicas & 7.4 & adsorption & 120 & 95.5 & [130] \\
\hline mesoporous cellular foam & 16.1 & adsorption/CLEAs & 139 & 77.4 & [132] \\
\hline micro-sized aggregates & 29.0 & Adsorption covalent & 2040 & 36.674 .8 & [133] \\
\hline stellate macroporous nanoparticles & 12.6 & adsorption & 40 & $>90$ & [134] \\
\hline wrinkled silica nanoparticles & 12.2 & adsorption & 150 & 125 & {$[136,137]$} \\
\hline wrinkled silica nanoparticles & 12.2 & covalent & 150 & 120 & [138] \\
\hline tannic acid template & $3.0-8.5$ & adsorption & 78-130 & - & [139] \\
\hline
\end{tabular}

\section{Immobilization of Cellulase on Mesostructured Silica}

When considering the immobilization of enzymes in general, and in particular of cellulases, there are the factors that must be taken into account in order to maximize the adsorption. First, the surface charge on the enzyme and the carrier must be opposite, as electrostatic interactions have a great influence on adsorption and desorption of the enzyme on the carrier [141]. The second is the matching between the size of the mesopores and the molecular diameter of the enzyme; that is, the pore size should be sufficiently large to accommodate the enzyme, but not too large to favour desorption [142]. Finally, the functionalization of the silica surface with hydrophobic groups can also play an important role in enzyme adsorption and desorption, as cellulases have a high affinity with hydrophobic surfaces. However, a high load does not always correspond to increased enzyme activity. The following works consider all these issues.

The first immobilization of cellulase on mesostructured silica materials was again on SBA-15 [143]. This is because SBA-15 is the first mesostructured siliceous material with pores large enough to accommodate bulky enzymes. Takimoto et al. [143] immobilized cellulase from Trichoderma viride in SBA-15 with different pore sizes-5.4, 8.9, and $11 \mathrm{~nm}$. All samples showed an optimal $\mathrm{pH}$ of adsorption equal to 4.0. At this $\mathrm{pH}$ value, cellulase was positively charged $(\mathrm{pI}=4.9)$, while SBA-15 was negatively charged $(\mathrm{pI}=3)$. The driving force for adsorption was thus supposed to be electrostatic interactions. The maximum adsorbed amount for the three samples was $7 \mathrm{mg}, 8.2 \mathrm{mg}$, and $8.3 \mathrm{mg}$ per $10 \mathrm{mg}$ of the respective silica. The activity of the three biocatalysts was measured in the hydrolysis of crystalline cellulose at $\mathrm{pH} 4.0$ and $37^{\circ} \mathrm{C}$. Despite the fact that the support with the largest pores showed a slightly greater amount of absorbed enzyme, the maximum activity was expressed by the support with intermediate pore size. In fact, the former only preserved $35 \%$ of the activity of the free form, while the latter exhibited $67.5 \%$. The results indicate a dependence of the activity on the matching of the silica pore size and the molecular size of cellulase $(5.2 \times 7.6 \times 11.3 \mathrm{~nm})$. As microcrystalline 
cellulose is too large to enter the pores of silica, the higher activity of the biocatalyst was explained with a greater accessibility of the enzyme active site. In fact, it was demonstrated that, in the $8.9 \mathrm{~nm}$ support, the enzyme was located at or very close to the pore entrance, while in the $11 \mathrm{~nm}$ support, the enzyme was primary located in the interior of the pores. Immobilized cellulase showed an increased storage stability with respect to free cellulase.

Hartono et al. [13] synthesized a series of organo-functionalized FDU-12 type mesoporous silica with very large pores up to $28 \mathrm{~nm}$ for the immobilization of cellulase by physical adsorption. They state that large pore size and high pore connectivity make FDU-12 materials particularly well suited for enzyme immobilization. However, surface functionalization is necessary to improve the interactions between the enzyme and the silica support, creating a beneficial microenvironment for catalysis. The synthesis was performed via co-condensation of TEOS and a suite of organosilanes: 3-aminopropyl- (APTES), 3-mercaptopropyl- (MPTMS), phenyl- (PTMS), and vinyl(VTMS) trialkoxysilane, and trimethylbenzene as pore expanding agent. On the basis of the size of the pore cavities and entrances and on preliminary adsorption of bovine serum albumin, S-APTES and S-VTMS were selected for further studies, were $\mathrm{S}$ stands for silica. S-APTES had a loading capacity slightly higher than S-VTMS (21.80 vs. $18.19 \mathrm{mg}$ of enzyme per gram of support). Both samples had a loading capacity higher than pure FDU-12 (10.35 mg per gram of support). The loading capacity of S-VTMS was attributed to hydrophobic interactions between the vinyl group and the enzyme, because, at the $\mathrm{pH}$ of adsorption (4.8), both the enzyme and the silica support are negatively charged. S-APTES surface is instead positively charged at $\mathrm{pH} 4.8$, thus the interaction with the enzyme negatively charged is mainly electrostatic. S-VTMS had a higher activity (70\% of the free enzyme activity) than S-APTES (3.4\% of the free enzyme activity) in the hydrolysis of carboxymethyl cellulose (CMC). The formation of amide bonds between the primary amine groups of APTES and carboxyl groups of aspartic and glutamic acids was demonstrated by C1s X-ray photoelectron spectroscopy (XPS) analysis. As the active site of cellulase contains these residues, the low activity of S-APTES can be because of the formation of amide bonds at the active site of the enzyme. Instead, the presence of hydrophobicity in S-VTMS created a benign microenvironment for cellulase activity. Storage stability experiments indicated that S-VTMS retained $80-100 \%$ of its initial activity after 15 days of storage, with very low leaching. In a later work, Harmoko et al. [144] optimized S-VTMS in terms of particle size and VTMS concentration during the co-condensation with TEOS. They synthesised micro- and nano-particles with a pore size of $9-10 \mathrm{~nm}$ and pore entrance of 5-6 nm, varying the VTMS/TEOS ratio from 5 to 20 . They found that cellulase immobilized on nanoparticles had higher activity than cellulase immobilized on microparticles. They explained this with the higher channel length of microparticles that can be easily blocked, leaving the enzyme inoperative. On the contrary, the short channel length of nanoparticles hinders the formation of inactive site along the pore channels, favouring an efficient contact between the enzyme and the substrate. The maximum catalytic activity was expressed by cellulase immobilized on nanoparticles synthesised with VTMS/TEOS $=5$, with the highest loading capacity.

Chang et al. [1] synthesized small pore (SP) $(2-5 \mathrm{~nm})$ and ultra-large pore (LP) $(20-40 \mathrm{~nm})$ silica nanoparticles. LP materials were obtained by co-condensation with APTMS (3-aminopropyltrimethoxysilane) and dimethyl phthalate as pore expander. After optimizing the reaction conditions for free Trichoderma reseei cellulase, they immobilized the enzyme on SP silica by physical adsorption and on LP silica by both physical adsorption and covalent binding. Covalent binding was performed by functionalizing LP silica with (3-trietoxysylilpropyl) succinic acid anhydride (TESP-SA), according to Scheme 4. 


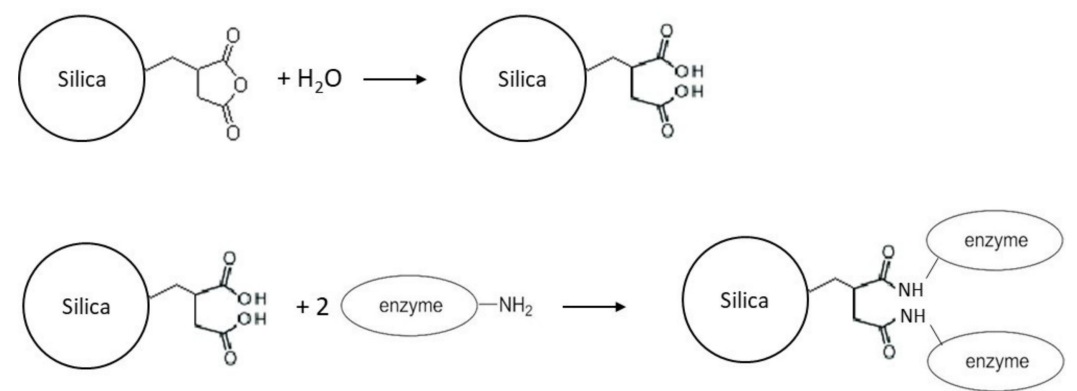

Scheme 4. Covalent linking of cellulase to (3-trietoxysylilpropyl) succinic acid anhydride (TESP-SA) functionalized silica.

The amount of immobilized cellulase was $292 \mathrm{mg}$, $468 \mathrm{mg}$, and $384 \mathrm{mg}$ per gram of support for SP, LP, and TESP-SA/LP, respectively. SP had the lowest amount of immobilized cellulase because of the small pore size with respect to cellulase molecular diameter (about $8 \mathrm{~nm}$ ). Furthermore, at $\mathrm{pH}=4.8$ used during adsorption and reaction, both the enzyme and the SP support were negatively charged. Instead, LP silica had a pore size much larger than the enzyme molecular size and its surface charge was close to zero, owing to the presence of both $\mathrm{Si}-\mathrm{OH}$ and $\mathrm{Si}_{-} \mathrm{NH}_{2}$ groups. Therefore, a contribution to physical adsorption was also owing to electrostatic interaction between cellulase and $\mathrm{Si}-\mathrm{NH}_{2}$ groups. The biocatalysts' performance was measured in the hydrolysis of pre-treated cellulose. Cellulose was pre-treated by the ionic liquid method [145], which produced cellulose oligomers. The glucose yields of the three biocatalysts were $33.30 \%, 77.89 \%$, and $83.79 \%$ respectively, against a glucose yield of free cellulase of approximately $85 \%$. These results proved the significance of a suitable pore size of the host material. SP silica showed the lowest yield also owing to difficult diffusion of cellulase oligomers into its small pores. TESP-SA/LP exhibited almost the same yield of free cellulase. It was inferred that the carboxylic groups on the support bind with the CBD of cellulose, even if there is no experimental evidence thereof. Storage stability was determined for all samples. TESP-SA/LP showed the best storage stability, giving a glucose yield of $86.56 \%$ after 23 days' storage at room temperature, attributed to the covalent linking that hindered enzyme leaching.

Functionalization of silica surface with APTES, followed by crosslinking with glutaraldehyde (see Scheme 2), is a common way to avoid the direct bonding between $-\mathrm{NH}_{2}$ of APTES and the carboxylic acids possibly present in the active site of the enzyme, as in the case of cellulase active sites. In fact, the aldehyde group of glutaraldehyde linked to the surface of silica binds mainly $\varepsilon$-amino groups of lysine residues in the protein. These residues are generally not involved in the catalytic site for the hydrolysis of cellulose [146]. Glutaraldehyde also acts as a spacer arm between the enzyme and the matrix, avoiding steric constraints.

Kannan and Jasra [147] covalently immobilized cellulase from Penicillium funicolosum on functionalized MCF. The functionalization reaction included amino functionalization with APTES, the reaction of $-\mathrm{NH}_{2}$ with a carboxyl of glutaraldehyde with the formation of an imine group $\mathrm{N}=\mathrm{C}$, the reduction of the imine bond with $\mathrm{NaBH}_{4}$, and finally the covalent attachment of enzyme $-\mathrm{NH}_{2}$ to the remaining glutaraldehyde carboxyl, as illustrated in Scheme 5. 


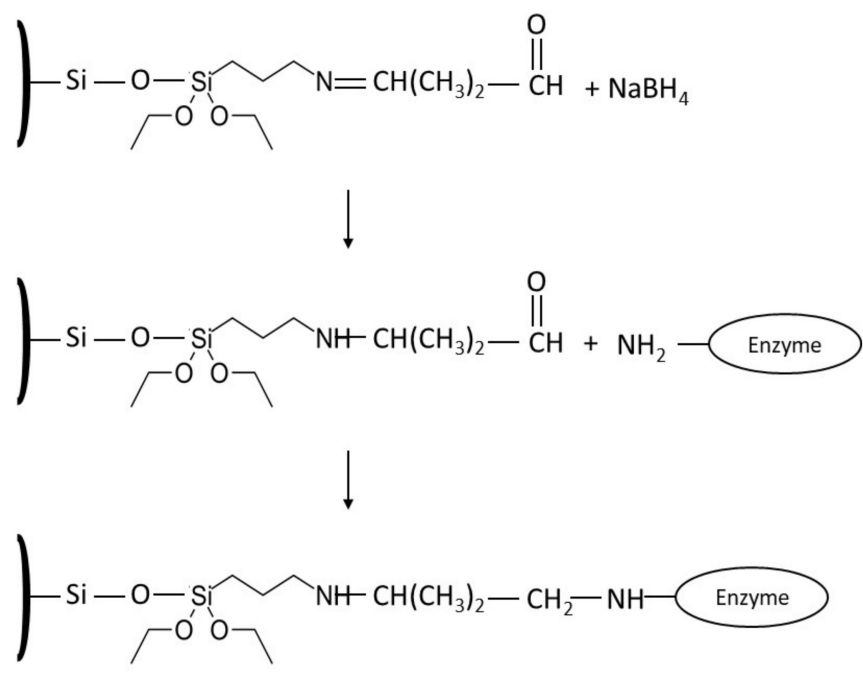

Scheme 5. Covalent linking of cellulase to glutaraldehyde functionalized silica with reduction by $\mathrm{NaBH}_{4}$.

The glutaration of MCF reduced the pore size of the support, $10.8 \mathrm{~nm}$ versus $21.8 \mathrm{~nm}$, but there was still enough space to accommodate cellulase. For the first time, the immobilized enzyme showed higher activity than the free one. This was attributed to the proven activity of the functional groups on surface modified MCF toward the hydrolysis of CMC. Moroever, a slightly higher $\mathrm{V}_{\max }$ was found for the immobilized enzyme in respect to the free one, $9.8 \mathrm{U} / \mathrm{mg}$ versus 5.3. It was argued that the high number of polar groups on surface modified $\mathrm{MCF}\left(-\mathrm{OH}\right.$ and $\left.\mathrm{NH}_{2}\right)$ stabilized the enzyme on the surface by hydrogen bonding, together with hydrophobic interactions, multipoint attachment, and electrostatic interactions. In fact, at the used $\mathrm{pH}=5$, the enzyme and the MCF surface have opposite charges. The pore size was large enough to host the enzyme and facilitate the diffusion of the substrate molecules (in fact, $\mathrm{K}_{\mathrm{M}}$ did not vary). The reusability of the immobilized biocatalyst was tested. Its activity decreased after every cycle, owing to continuous small loss of enzyme, and $66 \%$ of the initial activity was retained after 15 reaction cycles. With the same procedure, but without the $\mathrm{NaBH}_{4}$ reducing step, Yin et al. [2] immobilized cellulase on SBA-7, obtaining very similar results. They determined the kinetic constant in the hydrolysis of $\mathrm{CMC}$ at $\mathrm{pH} 4$ and found an eightfold increase in $\mathrm{V}_{\max }$, which was attributed to the increased stability of the enzyme after immobilization. Unlike the previous work, they found an increase in $\mathrm{K}_{\mathrm{M}}$ owing to diffusion limitation of the substrate inside the pores. It is possible that the pore size of functionalized SBA-7 is smaller than that of functionalized MCF, but pore size is not specified. Furthermore, they found an increased optimal temperature $\left(60\right.$ vs. $\left.40^{\circ} \mathrm{C}\right)$, which indicated that the support material retained the enzyme tertiary structure at higher temperatures. The activity of immobilized cellulase was higher in a wider range of $\mathrm{pH}$ values and the thermal stability measured at $60^{\circ} \mathrm{C}$ at various times (30-130 min) was increased, possibly owing to multipoint attachment. The immobilized cellulase retained $88 \%$ of initial activity after 11 cycles of reaction. Zhang et al. [148] applied a similar functionalization procedure to immobilize covalently cellulase on silica gel substrate. A commercial silica with pore size of 10.6-16.2 nm, which reduced to 7.7-10.6 nm after surface functionalization, was used. The amount of loaded cellulase was $18.8 \mathrm{mg}$ per gram of silica gel and retained only 7\% of its specific activity in the hydrolysis of CMC. The focus of this work was on the optimization of the enzyme reusability. It was found that the reusability of the enzyme was low when its activity was maximum, so the optimal working conditions $\left(\mathrm{pH}=6\right.$ and $\left.40^{\circ} \mathrm{C}\right)$ are the result of a compromise between activity and reusability. The immobilized enzyme exhibited a three-stage activity loss during reuse: from 1st to 7 th cycle, $82-100 \%$ of activity was retained; from 8 th to 13 th cycle, $60-48 \%$ of activity was retained; and from 14 th to 26 th cycle, $23-36 \%$ of activity was retained. After excluding experimentally the desorption of the enzyme from the support, they hypothesized that cellulase immobilized on the outer surface was denatured first, while the one in the vicinity of the pores 
was denatured at the second stage. The cellulase inside the pores denatured last as it was protected from conformational structure shifting. Apart from the high usability, the immobilized enzyme also showed high storage stability, retaining $92.4 \%$ of its initial activity after storage at $4{ }^{\circ} \mathrm{C}$ for 32 days.

Ungurean et al. [29] immobilized cellulase from Trichoderma reseei (Celluclasst, Novozyme) by sol-gel encapsulation using binary and ternary mixtures of tetramethoxysilane (TMOS) with metyl- (MeTMOS) and phenyltrimethoxysilane (PhTMOS), using two different synthesis methods and various additives (ionic liquid, PEG, or Tween 80 ). They determined the best performing materials in the hydrolysis of CMC at $\mathrm{pH} 4.8$ to derive from MeTMOS/TMOS 3:1 molar ratio and no additives. It resulted in more than $90 \%$ recovery of total enzymatic activity. Higher MeTMOS/TMOS ratios gave a slight decrease of the activity because the strong hydrophobic character of the support inhibited the activity of the immobilized enzyme in water, where a certain hydrophilic character, provided by unreacted $\mathrm{Si}-\mathrm{OH}$ groups, is required. The catalytic efficiency of the entrapped enzyme was investigated in the hydrolysis of microcrystalline cellulose Avicel PH101. After $24 \mathrm{~h}$ reaction, the immobilized enzyme gave a lower yield in glucose than the free one, but at longer reaction times; the two yields were similar, indicating that the decrease was of kinetic nature. As glucose is an inhibitor of cellulase, the activity of the free and immobilized enzyme was measured in the hydrolysis of CMC at increasing initial concentrations of glucose, finding that the immobilized enzyme lowered the inhibition effect. The $\mathrm{pH}$ stability of the immobilized enzyme was increased in the $\mathrm{pH}$ domain 5.5-7.0 and the thermal stability was $10-20 \%$ higher compared with free cellulase. These effects were explained with an increased rigidity of the encapsulated enzyme molecules that prevented denaturation and a microenvironment inside the porous structure that can protect against unfavourable environmental modifications. The kinetic parameters were determined in the hydrolysis of microcrystalline cellulose. $\mathrm{K}_{\mathrm{M}}$ for the immobilized cellulase was about half of that of free cellulase, explained with an enhancement of enzyme/substrate affinity. $V_{\max }$ showed a threefold decrease attributed to mass transfer resistance within the sol-gel matrix. Finally, reusability was tested. There was a progressive decrease of the enzyme residual activity, up to $20 \%$ residual activity after the 6 th reuse, attributed to leaching.

Hikeda et al. [149] immobilized separately two commercial cellulases (C1 and C2) on two commercial silica (S1 and S2) by physical adsorption. S1 was fumed silica, nonporous, and with a particle diameter of $7 \mathrm{~nm}$. S2 was Davisil chromatographic silica with particle diameters of 47-60 $\mu \mathrm{m}$ and pore size of $6.0 \mathrm{~nm}$. They investigated the interaction between the two kinds of cellulase containing particles with the surface of cellulose by scanning electron microscopy (SEM). Cellulose was found to differentially interact with the two kinds of particles. Cellulose surface was uniformly covered with S1 nanoparticles, while S2 surface was only partially bound to cellulose. It was found that, in the hydrolysis of microcrystalline cellulose, C1S1 and C2S1 retained more than 90\% activity, while C1S2 and C2S2 only retained $60 \%$. It is clear that the pores of S1 were too small compared with the size of the enzymes $(6 \times 5 \times 4 \mathrm{~nm}, 5.2 \times 7.6 \times 11.3 \mathrm{~nm}$, and $1.3 \times 7.9 \mathrm{~nm}-4.2 \times 25.2 \mathrm{~nm})$. Some of them, the smaller ones, managed to get inside the pores, but a part of the enzyme blocked the entrance of the pores, making them inaccessible to the substrate. It is also clear that the pores were too small for microcrystalline cellulose to diffuse inside them, and the only part of enzyme that was active was that on the surface of the particles. Differences in physical interactions of the particles with the surface of cellulose also contributed to the observed differences. The interesting hypothesis is that $\mathrm{S} 1$ could behave like scaffold proteins and provide a cellulosome-like environment.

Chen et al. [150] synthesized two mesoporous silica with different pore sizes of $17.6 \mathrm{~nm}$ (MS-17.6) and $3.8 \mathrm{~nm}$ (MS-3.8). The samples were prepared by a seeded-growth method using $\mathrm{Na}_{2} \mathrm{O}-\mathrm{SiO}_{2}$ as silica source and cetyl trimethylammonium bromide (CTAB) as structure directing agent. They used these mesoporous materials to immobilize cellulase from Acremonium by pure physical adsorption. This cellulase has elongated molecules, with a long axis of $12.4 \mathrm{~nm}$ and a short axis of $3.7 \mathrm{~nm}$. The enzyme loading exhibited a clear correlation with the pore size of the mesostructures. The loading of MS-17.6, with pore size close to the long axis of cellulase, was almost 1.2 times higher than that of MS-3.8, with pore slightly larger than the short axis of cellulase (410 vs. $315 \mathrm{mg}$ per gram of matrix). 
This was attributed to the blocking of the pore entrance by some cellulase molecules in MS-3.8. Instead, in MS-17.6, there was enough space for the cellulase molecules to adjust as a dense and ordered arrangement. The activity of the two biocatalysts, measured in the hydrolysis of CMC at pH 5.0 and $50{ }^{\circ} \mathrm{C}$, showed an opposite trend in respect to loading. MS-3.8 displayed a higher specific activity (63.3\% of free cellulase) than MS-17.6 (26.6\%). It was speculated that, in MS-3.8, cellulase preserved its native structure, and the molecules were stuck in the pore entrance, increasing the accessibility of the active site. In MS-17.6, the dense and ordered arrangement hampered the conformational flexibility of cellulase, lowering its activity. In fact, cellulase molecules need a conformational change in the interaction with the substrate. These results demonstrate that a higher load is not always related to a higher enzyme activity.

Another important feature of mesoporous silica lies in the possibility of providing it with a magnetic core of magnetite $\left(\mathrm{Fe}_{3} \mathrm{O}_{4}\right)$. Core-shell magnetite-silica nanoparticles can be synthesised by controlling the reaction conditions using the proper surfactant. Magnetic supports allows recovery of the immobilized enzyme from a reactor by simply applying a magnetic field, without the need for tedious and time-consuming decantation, centrifugation, or filtration procedures. So far, only a few studies have been carried out on the immobilization of cellulase in this kind of material. Sulaiman et al. [151] studied the adsorption kinetics of cellulase and xylanase immobilized on magnetically separable, hierarchically ordered mesocellular mesoporous silica, while Lee et al. used cellulase immobilized on $\mathrm{Fe}_{3} \mathrm{O}_{4}$ loaded mesoporous silica nanoparticles in cascading cellulose-glucose-fructose [152] and fructose-5-hydroxymethylfurfural (HMF) [153] conversion. HMF is a versatile platform for biofuel production.

\section{Conclusions}

Mesoporous silica materials have proven to be very suitable for the immobilization of both cellulase and $\beta$-glucosidase. There are two fundamental aspects that must be considered for a successful immobilization: the activity of the immobilized enzyme and its reusability. The operational stability of a biocatalyst is of crucial importance for its use in large-scale applications. Generally, both BG and cellulase immobilized in mesostructured silica retained more than $70 \%$ of the free enzyme activity. In some cases, an increase in activity was even found. BG immobilized in wrinkled silica nanoparticles, both by adsorption and by covalent attachment, showed an increase in activity that was attributed to the particular pore morphology of these silica materials, which created an optimal microenvironment for catalysis. Cellulase immobilized on functionalized MCF (APTES + GA) showed higher activity than the free one. This was attributed to the proven activity of the functional groups on surface modified MCF toward the hydrolysis of CMC. Most of the produced biocatalysts showed a good operational stability, being reusable with a small loss of activity at least five times.

The results of these studies also highlight the fundamental parameters for an effective immobilization. Of particular importance is the matching between the pore size and the molecular diameter of the enzyme. This is important to obtain high loads and low leaching. Although bigger pore can increase the loading, they can favour the diffusion of the enzyme from the pores and inhibit its activity owing to crowding of the protein in a confined space as a possible cause of denaturation. The position in which the enzyme is immobilized is also crucial in order to obtain high activity. This is particularly critical for cellulase, which must act on an insoluble substrate. If the enzyme is located at or very close to the pore entrance, its active site is more accessible than an enzyme located deep in the pores. In fact, the substrate must not diffuse inside the pores to reach the active site. Another important parameter is the immobilization $\mathrm{pH}$. The $\mathrm{pH}$ value must be chosen so that the support surface and the enzyme carry opposite charges for the maximization of the loading and minimization of enzyme leaching through electrostatic interactions. Finally, the presence of non-polar organic groups such as vinyl group can stabilize the enzyme-support complex through hydrophobic interactions, as both cellulase and BG have large hydrophobic areas. 
Thermal stability of cellulolytic enzymes immobilized into mesoporous silica materials is generally improved. This is because of the formation of multipoint attachment (covalent immobilization) or the interaction with the pore walls (adsorption and entrapment) that inhibited the conformational freedom and thermal vibration, inducing an increase in enzyme rigidity that prevents the immobilized protein from unfolding and denaturing under high temperature conditions.

Further studies are required to optimize, at the same time, activity, operational stability, thermal and $\mathrm{pH}$ resistance, and easy recovery. There is a general lack of experimental data in continuous reactors. One research field that has yet to be fully explored is the immobilization of BG and cellulase on core-shell silica magnetic particles for easy recovery of the biocatalyst.

Furthermore, we recommend the use of natural cellobiose and cellulose substrates for the determination of the catalytic performance. In fact, artificial substrates such as p-NPG are easily accommodated in the substrate binding site of BG. Cellobiose requires a conformational change through the rotation of the glucoside bond to fit the substrate binding site, so there is no guarantee that a BG capable of hydrolysing p-NPG is also active towards cellobiose. Furthermore, CMC is water-soluble, while cellulose is not. This poses a problem of diffusion and adsorption of the immobilized cellulase on the substrate, which can affect its activity.

Funding: This research received no external funding.

Conflicts of Interest: The authors declare no conflict of interest.

\section{References}

1. Chang, R.H.Y.; Jang, J.; Wu, K.C.W. Cellulase immobilized mesoporous silica nanocatalysts for efficient cellulose-to-glucose conversion. Green Chem. 2011, 13, 2844-2850. [CrossRef]

2. Yin, H.; Su, Z.L.; Shao, H.; Cai, J.; Wang, X.; Yin, H. Immobilization of cellulase on modified mesoporous silica shows improved thermal stability and reusability. Afr. J. Microbiol. Res. 2013, 7, 3248-3253.

3. Bhat, M. Cellulases and related enzymes in biotechnology. Biotechnol. Adv. 2000, 18, 355-383. [CrossRef]

4. Bhat, M.K.; Bhat, S. Cellulose degrading enzymes and their potential industrial applications. Biotechnol. Adv. 1997, 15, 583-620. [CrossRef]

5. Kitaoka, M.; Taniguchi, H.; Sasaki, T. A simple method of cellulase immobilization on a modified silica support. J. Ferment. Bioeng. 1989, 67, 182-185. [CrossRef]

6. Walker, L.P.; Wilson, D.B. Enzymatic hydrolysis of cellulose: An overview. Bioresour. Technol. 1991, 36, 3-14. [CrossRef]

7. Reis, C.L.B.; Sousa, E.Y.A.D.; Serpa, J.D.F.; Oliveira, R.C.; Santos, J.C.S.D. Design of immobilized enzyme biocatalysts: Drawbacks and opportunities. Quim. Nova 2019, 42, 768-783. [CrossRef]

8. Khoshnevisan, K.; Poorakbar, E.; Baharifar, H.; Barkhi, M. Recent advances of cellulase immobilization onto magnetic nanoparticles: An update review. Magnetochemistry 2019, 5, 36. [CrossRef]

9. Andriani, D.; Sunwoo, C.; Ryu, H.W.; Prasetya, B.; Park, D.H. Immobilization of cellulase from newly isolated strain Bacillus subtilis TD6 using calcium alginate as a support material. Bioprocess. Biosyst. Eng. 2012, 35, 29-33. [CrossRef]

10. Anuradha, J.S.; Valli, N.C. Immobilization of Aspergillus nidulans SU04 cellulase on modified activated carbon. J. Therm. Anal. Calorim. 2012, 109, 193-202. [CrossRef]

11. Magner, E. Immobilisation of enzymes on mesoporous silicate materials. Chem. Soc. Rev. 2013, 42, 6213-6222. [CrossRef] [PubMed]

12. Hartmann, M.; Jung, D. Biocatalysis with enzymes immobilized on mesoporous hosts: The status quo and future trends. J. Mater. Chem. 2010, 20, 844-857. [CrossRef]

13. Hartono, S.B.; Qiao, S.Z.; Liu, J.; Jack, K.; Ladewig, B.P.; Hao, Z.; Lu, G.Q.M. Functionalized mesoporous silica with very large pores for cellulase immobilization. J. Phys. Chem. C 2010, 114, 8353-8362. [CrossRef]

14. Chong, A.S.M.; Zhao, X.S. Design of large-pore mesoporous materials for immobilization of penicillin G acylase biocatalyst. Catal. Today 2004, 93, 293-299. [CrossRef]

15. Yiu, H.H.P.; Botting, C.H.; Botting, N.P.; Wright, P.A. Size selective protein adsorption on thiol-functionalised SBA-15 mesoporous molecular sieve. Phys. Chem. Chem. Phys. 2001, 3, 2983-2985. [CrossRef] 
16. Kao, H.M.; Chang, P.C.; Wu, J.D.; Chiang, A.S.; Lee, C.H. Direct synthesis, characterization and solid-state NMR spectroscopy of large-pore vinyl-functionalized cubic mesoporous silica FDU-12. Microporous Mesoporous Mater. 2006, 97, 9-20. [CrossRef]

17. Koeller, K.M.; Wong, C.H. Enzymes for chemical synthesis. Nature 2001, 409, 232. [CrossRef]

18. Arsalan, A.; Younus, H. Enzymes and nanoparticles: Modulation of enzymatic activity via nanoparticles. Int. J. Biol. Macromol. 2018, 118, 1833-1847. [CrossRef]

19. Mateo, C.; Palomo, J.M.; Fernandez-Lorente, G.; Guisan, J.M.; Fernandez-Lafuente, R. Improvement of enzyme activity, stability and selectivity via immobilization techniques. Enzym. Microb. Technol. 2007, 40, 1451-1463. [CrossRef]

20. Nelson, J.M.; Grinn, E.G. Adsorption of invertase. J. Am. Chem. Soc. 1916, 38, 1109-1115. [CrossRef]

21. Bommarius, A.S.; Paye, M.F. Stabilizing biocatalysts. Chem. Soc. Rev. 2013, 42, 6534-6565. [CrossRef] [PubMed]

22. Sheldon, R.A. Enzyme immobilization: The quest for optimum performance. Adv. Synth. Catal. 2007, 349, 1289-1307. [CrossRef]

23. Daoud, F.B.O.; Kaddour, S.; Sadoun, T. Adsorption of cellulase Aspergillus niger on a commercial activated carbon: Kinetics and equilibrium studies. Colloids Surf. B 2010, 75, 93-99. [CrossRef]

24. Kourkoutas, Y.; Bekatorou, A.; Banat, I.M.; Marchant, R.; Koutinas, A.A. Immobilization technologies and support materials suitable in alcohol beverages production: A review. Food Microbiol. 2004, 21, 377-397. [CrossRef]

25. Pierre, A.C. The sol-gel encapsulation of enzymes. Biocatal. Biotransform. 2004, 22, 145-170. [CrossRef]

26. Vidinha, P.; Augusto, V.; Almeida, M.; Fonseca, I.; Fidalgo, A.; Ilharco, L.; Cabral, J.M.S.; Barreiros, S. Sol-gel encapsulation: An efficient and versatile immobilization technique for cutinase in non-aqueous media. J. Biotechnol. 2006, 121, 23-33. [CrossRef]

27. Zarcula, C.; Kiss, C.; Corîci, L.; Croitoru, R.; Csunderlik, C.; Peter, F. Combined sol-gel entrapment and adsorption method to obtain solid-phase lipase biocatalyst. Rev. Chim. 2009, 60, 922-927.

28. Tomin, A.; Weiser, D.; Hellner, G.; Bata, Z.; Corici, L.; Peter, F.; Koczka, B.; Poppe, L. Fine-tuning the second generation sol-gel lipase immobilization with ternary alkoxysilane precursor systems. Process. Biochem. 2011, 46, 52-58. [CrossRef]

29. Ungurean, M.; Paul, C.; Peter, F. Cellulase immobilized by sol-gel entrapment for efficient hydrolysis of cellulose. Bioproc. Biosys. Eng. 2013, 36, 1327-1338. [CrossRef]

30. Karube, I.; Tanaka, S.; Shirai, T.; Suzuki, S. Hydrolysis of cellulose in a cellulase-bead fluidized bed reactor. Biotechnol. Bioeng. 1977, 19, 1183-1191. [CrossRef]

31. Cao, L.; van Langen, L.; Sheldon, R.A. Immobilised enzymes: Carrier-bound or carrier-free? Curr. Opin. Biotech. 2003, 14, 387-394. [CrossRef]

32. Sheldon, R.A.; Sorgedrager, M.E.N.N.O.; Janssen, M.H. Use of cross-linked enzyme aggregates (CLEAs) for performing biotransformations. Chim. Oggi 2007, 25, 62.

33. Li, B.; Dong, S.L.; Xie, X.L.; Xu, Z.B.; Li, L. Preparation and properties of cross-linked enzyme aggregates of cellulase. In Advanced Materials Research; Trans Tech Publications Ltd.: Bach, Switzerland, 2012; Volume 581, pp. 257-260.

34. Branda, F.; Silvestri, B.; Costantini, A.; Luciani, G. Effect of exposure to growth media on size and surface charge of silica based Stöber nanoparticles: A DLS and ל-potential study. J. Sol Gel Sci. Technol. 2015, 73, 54-61. [CrossRef]

35. Thomas, J.M.; Johnson, B.F.; Raja, R.; Sankar, G.; Midgley, P.A. High-performance nanocatalysts for single-step hydrogenations. Acc. Chem. Res. 2003, 36, 20-30. [CrossRef] [PubMed]

36. Zhao, X.S.; Lu, M.G.; Song, C. Immobilization of aluminum chloride on MCM-41 as a new catalyst system for liquid-phase isopropylation of naphthalene. J. Mol. Catal. A Chem. 2003, 191, 67-74. [CrossRef]

37. Mateo, C.; Grazu, V.; Palomo, J.M.; Lopez-Gallego, F.; Fernandez-Lafuente, R.; Guisan, J.M. Immobilization of enzymes on heterofunctional epoxy supports. Nat. Protoc. 2007, 2, 1022. [CrossRef] [PubMed]

38. Popat, A.; Hartono, S.B.; Stahr, F.; Liu, J.; Qiao, S.Z.; Lu, G.Q.M. Mesoporous silica nanoparticles for bioadsorption, enzyme immobilisation, and delivery carriers. Nanoscale 2011, 3, 2801-2818. [CrossRef]

39. McBain, J.W. The Sorption of Gases and Vapors by Solids; Routledge and Sons: London, UK, 1932; p. 169.

40. Barrer, R.M.; Brook, D.W. Molecular diffusion in chabazite, mordenite, and levynite. Trans. Faraday Soc. 1953, 49, 1049-1059. [CrossRef] 
41. Breck, D.W.; Eversole, W.G.; Milton, R.M. New synthetic crystalline zeolites. J. Am. Chem. Soc. 1956, 78, 2338-2339. [CrossRef]

42. Davis, M.E.; Lobo, R.F. Zeolite and molecular sieve synthesis. Chem. Mater. 1992, 4, 756-768. [CrossRef]

43. Mitchell, P.C.H. Zeolite-encapsulated metal complexes: Biomimetic catalysts. Chem. Ind. 1991, 6, 308-311.

44. Ozin, G.A. Nanochemistry: Synthesis in diminishing dimensions. Adv. Mater. 1992, 10, 612-649. [CrossRef]

45. Yanagisawa, T.; Schimizu, T.; Kiroda, K.; Kato, C. The preparation of alkyltrimethylammonium-kanemite complexes and their conversion to mesoporous materials. Bull. Chem. Soc. Jpn. 1990, 63, 988-992. [CrossRef]

46. Beck, J.S.; Calabro, D.C.; McCullen, S.B.; Pelrine, B.P.; Schmitt, K.D.; Vartuli, J.C. Method for Functionalizing Synthetic Mesoporous Crystalline Material. U.S. Patent 2,069,722, 27 May 1992.

47. Kresge, C.T.; Leonowicz, M.E.; Roth, W.J.; Vartuli, J.C.; Beck, J.S. Ordered mesoporous molecular sieves synthesized by a liquid-crystal template mechanism. Nature 1992, 359, 710-712. [CrossRef]

48. AlOthman, Z.A.; Apblett, A.W. Metal ion adsorption using polyamine-functionalized mesoporous materials prepared from bromopropyl-functionalized mesoporous silica. J. Hazard. Mater. 2010, 182, 581-590. [CrossRef]

49. Parida, K.M.; Dash, S.S. Manganese containing MCM-41: Synthesis, characterization and catalytic activity in the oxidation of ethylbenzene. J. Mol. Catal. A 2009, 306, 54-61. [CrossRef]

50. Chen, J.; Xia, N.; Zhou, T.; Tan, S.; Jiang, F. Mesoporous carbon spheres: Synthesis, characterization and supercapacitance. Int. J. Electrochem. Sci. 2009, 4, 1063-1073.

51. Beck, J.S.; Vartuli, J.C.; Roth, W.J.; Leonowicz, M.E.; Kresge, C.T.; Schmitt, K.D.; Chu, C.T.W.; Olson, D.H.; Sheppard, E.W.; McCullen, S.B.; et al. A new family of mesoporous molecular sieves prepared with liquid crystal templates. J. Am. Chem. Soc. 1992, 114, 10834-10843. [CrossRef]

52. Yang, X.Y.; Zhang, S.B.; Qiu, Z.M.; Tian, G.; Feng, Y.F.; Xiao, F.S. Stable ordered mesoporous silica materials templated by high-temperature stable surfactant micelle in alkaline media. J. Phys. Chem. B 2004, 108, 4696-4700. [CrossRef]

53. Di Renzo, F.; Cambon, H.; Dutarte, R. A 28-year-old Synthesis of Micelle-templated mesoporous silica. Microporous Mater. 1997, 10, 283-286. [CrossRef]

54. Lok, B.M.; Cannon, T.R.; Messina, C.A. The role of organic molecules in molecular sieve synthesis. Zeolites 1983, 3, 282-291. [CrossRef]

55. Chen, C.Y.; Burkett, S.L.; Li, H.X.; Davis, M.E. Studies on mesoporous materials. II. Synthesis mechanism of MCM-41. Microporous Mater. 1993, 2, 27-34. [CrossRef]

56. Monnier, A.; Schüth, F.; Huo, Q.; Kumar, D.; Margolese, D.; Maxwell, R.S.; Stucky, G.D.; Krishnamurty, M.; Petroff, P.; Firoouzi, A.; et al. Cooperative formation of inorganic-organic interfaces in the synthesis of silicate mesostructures. Science 1993, 261, 1299-1303. [CrossRef] [PubMed]

57. Steel, A.; Carr, S.W.; Anderson, M.W. 14N NMR study of surfactant mesophases in the synthesis of mesoporous silicates. J. Chem. Soc. Chem. Commun. 1994, 13, 1571-1572. [CrossRef]

58. Broekhoff, J.C.P. Mesopore determination from nitrogen sorption isotherms: Fundamentals, scope, limitations. Stud. Surf. Sci. Catal. 1979, 3, 663-684.

59. Shields, J.E.; Lowell, S.; Thomas, M.A.; Thommes, M. Characterization of Porous Solids and Powders: Surface Area, Pore Size and Density; Kluwer Academic Publisher: Boston, MA, USA, 2004; pp. 43-45.

60. Lawrence, M.J. Surfactant systems: Their use in drug delivery. Chem. Soc. Rev. 1994, 23, 417-424. [CrossRef]

61. Myers, D. Surfactant Science and Technology; VCH: New York, NY, USA, 1992.

62. Diaz, J.F.; Balkus, K.J., Jr. Enzyme immobilization in MCM-41 molecular sieve. J. Mol. Catal. B Enzym. 1996, 2, 115-126. [CrossRef]

63. Washmon-Kriel, L.; Jimenez, V.L.; Balkus, K.J., Jr. Cytochrome c immobilization into mesoporous molecular sieves. J. Mol. Catal. B Enzym. 2000, 10, 453-469. [CrossRef]

64. Branda, F.; Malucelli, G.; Durante, M.; Piccolo, A.; Mazzei, P.; Costantini, A.; Silvestri, B.; Pennetta, M.; Bifulco, A. Silica treatments: A fire retardant strategy for hemp fabric/epoxy composites. Polymers 2016, 8 , 313. [CrossRef]

65. Zhao, D.; Huo, Q.; Feng, J.; Chmelka, B.F.; Stucky, G.D. Nonionic triblock and star diblock copolymer and oligomeric surfactant syntheses of highly ordered, hydrothermally stable, mesoporous silica structures. J. Am. Chem. Soc. 1998, 120, 6024-6036. [CrossRef]

66. Wei, Y.; Jin, D.; Ding, T.; Shih, W.H.; Liu, X.; Cheng, S.Z.D.; Fu, Q. A non-surfactant templating route to mesoporous silica materials. Adv. Mater. 1998, 10, 313-316. [CrossRef] 
67. Wei, Y.; Xu, J.; Dong, H.; Dong, J.; Qiu, K.; Jansen-Varnum, S.A. Preparation and physisorption characterization of D-glucose-templated mesoporous silica sol-gel materials. Chem. Mater. 1999, 11, 2023-2029. [CrossRef]

68. Lü, Y.; Guo, Y.; Wang, Y.; Liu, X.; Wang, Y.; Guo, Y.; Zhang, Z.; Lu, G. Immobilized penicillin G acylase on mesoporous silica: The influence of pore size, pore volume and mesophases. Microporous Mesoporous Mater. 2008, 114, 507-510. [CrossRef]

69. Serra, E.; Mayoral, Á.; Sakamoto, Y.; Blanco, R.M.; Díaz, I. Immobilization of lipase in ordered mesoporous materials: Effect of textural and structural parameters. Microporous Mesoporous Mater. 2008, 114, 201-213. [CrossRef]

70. Shui, W.; Fan, J.; Yang, P.; Liu, C.; Zhai, J.; Lei, J.; Yan, Y.; Zhao, D.Y.; Chen, X. Nanopore-based proteolytic reactor for sensitive and comprehensive proteomic analyses. Anal. Chem. 2006, 78, 4811-4819.

71. Fan, J.; Yu, C.; Lei, J.; Zhang, Q.; Li, T.; Tu, B.; Zhou, W.; Zhao, D.Y. Low-temperature strategy to synthesize highly ordered mesoporous silicas with very large pores. J. Am. Chem. Soc. 2005, 127, 10794-10795. [CrossRef] [PubMed]

72. Schmidt-Winkel, P.; Lukens, W.W.; Yang, P.; Margolese, D.I.; Lettow, J.S.; Ying, J.Y.; Stucky, G.D. Microemulsion templating of siliceous mesostructured cellular foams with well-defined ultralarge mesopores. Chem. Mater. 2000, 12, 686-696. [CrossRef]

73. Fan, J.; Yu, C.; Gao, F.; Lei, J.; Tian, B.; Wang, L.; Luo, Q.; Tu, B.; Zhou, W.; Zhao, D. Cubic mesoporous silica with large controllable entrance sizes and advanced adsorption properties. Angew. Chem. Int. Ed. 2003, 42, 3146-3150. [CrossRef]

74. Kimura, T.; Suzuki, M.; Ikeda, T.; Kato, K.; Maeda, M.; Tomura, S. Silica-based mesoporous materials derived from Ti containing layered polysilicate kanemite. Micropor. Mesopor. Mat. 2006, 95, 146-153. [CrossRef]

75. Baú, L.; Bártovaá, B.; Arduini, M.; Mancin, F. Surfactant-free synthesis of mesoporous and hollow silicananoparticles with an inorganic template. Chem. Commun. 2009, 7584-7586.

76. Mukherjee, I.; Mylonakis, A.; Guo, Y.; Samuel, S.P.; Li, S.; Wei, R.Y.; Kojtari, A.; Wei, Y. Effect of nonsurfactant template content on the particle size and surface area of monodisperse mesoporous silica nanospheres. Microporous Mesoporous Mater. 2009, 122, 168-174. [CrossRef]

77. Gao, Z.; Zharov, I. Large pore mesoporous silica nanoparticles by templating with a nonsurfactant molecule, tannic acid. Chem. Mater. 2014, 26, 2030. [CrossRef]

78. Mori, T.; Rezai-Zadeh, K.; Koyama, N.; Arendash, G.W.; Yamaguchi, H.; Kakuda, N.; Horikoshi-Sakuraba, Y.; Tan, J.; Town, T. Tannic acid is a natural $\beta$-secretase inhibitor that prevents cognitive impairment and mitigates Alzheimer-like pathology in transgenic mice. J. Biol. Chem. 2012, 287, 6912-6927. [CrossRef] [PubMed]

79. Hagerman, A.E.; Riedl, K.M.; Jones, G.A.; Sovik, K.N.; Ritchard, N.T.; Hartzfeld, P.W.; Riechel, T.L.J. High molecular weight plant polyphenolics (Tannins) as biological antioxidants. Agric. Food Chem. 1998, 46, 1887-1892. [CrossRef]

80. Moon, D.; Lee, J. Tunable synthesis of hierarchical mesoporous silica nanoparticles with radial wrinkle structure. Langmuir 2012, 28, 12341-12347. [CrossRef] [PubMed]

81. Polshettiwar, V.; Thivolle-Cazat, J.; Taoufik, M.; Stoffelbach, F.; Norsic, S.; Basset, J.M. Hydro-metathesis of Olefins: A Catalytic Reaction Using a Bifunctional Single-Site Tantalum Hydride Catalyst Supported on Fibrous Silica (KCC-1) Nanospheres. Angew. Chem. Int. Ed. 2011, 50, 2747-2751. [CrossRef] [PubMed]

82. Pang, J.; Zhou, G.; Liu, R.; Li, T. Esterification of oleic acid with methanol by immobilized lipase on wrinkled silica nanoparticles with highly ordered, radially oriented mesochannels. Mater. Sci. Eng. C 2016, 59, 35-42. [CrossRef]

83. Pan, W.; Ye, J.; Ning, G.; Lin, Y.; Wang, J. A novel synthesis of micrometer silica hollow sphere. Mater. Res. Bull. 2009, 44, 280-283. [CrossRef]

84. Zhang, H.; Li, Z.; Xu, P.; Wu, R.; Jiao, Z. A facile two step synthesis of novel chrysanthemum-like mesoporous silica nanoparticles for controlled pyrene release. Chem. Commun. 2010, 46, 6783-6785. [CrossRef]

85. Al Othman, Z.A.; Apblett, A.W. Preparation of mesoporous silica with grafted chelating agents for uptake of metal ions. Chem. Eng. J. 2009, 155, 916-924. [CrossRef]

86. Al Othman, Z.A.; Apblett, A.W. Synthesis and characterization of a hexagonal mesoporous silica with enhanced thermal and hydrothermal stabilities. Appl. Surf. Sci. 2010, 256, 3573-3580. [CrossRef]

87. Mercier, L.; Pinnavaia, T.J. Access in mesoporous materials: Advantages of a uniform pore structure in the design of a heavy metal ion adsorbent for environmental remediation. Adv. Mater. 1997, 9, 500-503. [CrossRef]

88. Feng, X.; Fryxell, G.E.; Wang, L.Q.; Kim, Y.A.; Liu, J.; Kemner, K.M. Functionalized monolayers on ordered mesoporous supports. Science 1997, 276, 923-926. [CrossRef] 
89. Van Rhijn, W.M.; DeVos, D.E.; Sels, B.F.; Bossaert, W.D.; Jacobs, P.A. Sulfonic acid functionalized ordered mesoporous materials as catalysts for condensation and esterification reactions. Chem. Commun. 1998, 3 , 317-318. [CrossRef]

90. Lin, V.S.Y.; Radu, D.R.; Han, M.K.; Deng, W.; Kuroki, S.; Shanks, B.H.; Pruski, M. Oxidative polymerization of 1,4-diethynylbenzene into highly conjugated poly(phenylene butadiynylene) within the channels of surface-functionalized mesoporous silica and alumina materials. J. Am. Chem. Soc. 2002, 124, 9040-9041. [CrossRef]

91. Mbaraka, I.K.; Radu, D.R.; Lin, V.S.Y.; Shanks, B.H. Organosulfonic acid-functionalized mesoporous silicas for the esterification of fatty acid. J. Catal. 2003, 219, 329-336. [CrossRef]

92. Anwander, R. Surface organometallic chemistry at periodic mesoporous silica. Chem. Mater. 2001, 13, 4419-4438. [CrossRef]

93. Kimura, T.; Saeki, S.; Sugahara, Y.; Kuroda, K.A. Organic modification of FSM-type mesoporous silicas derived from kanemite by silylation. Langmuir 1999, 15, 2794-2798. [CrossRef]

94. Lim, M.H.; Stein, A. Comparative studies of grafting and direct syntheses of inorganic-organic hybrid mesoporous materials. Chem. Mater. 1999, 11, 3285-3295. [CrossRef]

95. Hudson, S.; Cooney, J.; Magner, E. Proteins in mesoporous silicates. Angew. Chem. Int. Ed. 2008, 47, 8582-8594. [CrossRef]

96. Al Othman, Z.A. A Review: Fundamental Aspects of Silicate Mesoporous Materials. Materials 2012, 5, 2874-2902. [CrossRef]

97. Dashtban, M.; Schraft, H.; Qin, W. Fungal bioconversion of lignocellulosic residues; opportunities \& perspectives. Int. J. Biol. Sci. 2009, 5, 578-594. [PubMed]

98. Cherubini, F. The biorefinery concept: Using biomass instead of oil for producing energy and chemicals. Energy Convers. Manag. 2010, 51, 1412-1421. [CrossRef]

99. Chen, L.; Gao, K.; Zhang, C.; Lang, W. Alternative fuels for IC engines and jet engines and comparison of their gaseous and particulate matter emissions. In Advanced Biofuels; Woodhead Publishing: Sawston, UK, 2019; pp. 17-64.

100. Festucci-Buselli, R.A.; Otoni, W.C.; Joshi, C.P. Structure, organization, and functions of cellulose synthase complexes in higher plants. Braz. J. Plant. Physiol. 2007, 19, 1-13. [CrossRef]

101. Laureano-Perez, L.; Teymouri, F.; Alizadeh, H.; Dale, B.E. Understanding factors that limit enzymatic hydrolysis of biomass: Characterization of pretreated corn stover. Appl. Biochem. Biotechnol. 2005, 121, 1081-1099. [CrossRef]

102. Saha, B.C. Hemicellulose bioconversion. J. Ind. Microbiol. Biotechnol. 2003, 30, 279-291. [CrossRef]

103. Avgerinos, C.G.; Wang, D.I.C. Selective delignification for fermentation enhancement. Biotechnol. Bioeng. 1983, 25, 67-83. [CrossRef]

104. Holtzapple, C.M.T. Fundamental factors affecting biomass enzymatic reactivity. Appl. Biochem. Biotechnol. 2000, 84, 5-37.

105. Alvira, P.; Tomas-Pejo, E.; Ballesteros, M.; Negro, M.J. Pretreatment technologies for an efficient bioethanol production process based on enzymatic hydrolysis: A review. Bioresour. Technol. 2010, 101, 4851-4861. [CrossRef]

106. Davis, G.; Henrissat, B. Structure and mechanism of glycosyl hydrolases. Structure 1995, 3, 853-859. [CrossRef]

107. Aro, N.; Pakula, T.; Pentilla, M. Transcriptional regulation of plant cell wall degradation by filamentous fungi. FEMS Microbiol. Rev. 2005, 29, 719-739. [CrossRef] [PubMed]

108. Zhang, Y.H.P.; Lynd, L.R. Toward an aggregated understanding of enzymatic hydrolysis of cellulose: Noncomplexed cellulose systems. Biotechnol. Bioeng. 2004, 88, 797-824. [CrossRef] [PubMed]

109. Wang, M.; Li, Z.; Fang, X.; Wang, L.; Qu, Y. Cellulolytic enzyme production and enzymatic hydrolysis for second-generation bioethanol production. Adv. Biochem. Eng. Biotechnol. 2012, 128, 1-24. [PubMed]

110. Teeri, T.; Koivula, A.; Linder, M.; Wohlfahrt, G.; Divne, C.; Jones, T. Trichoderma reesei cellobiohydrolases: Why so efficient on crystalline cellulose? Biochem. Soc. Trans. 1998, 26, 173-178. [CrossRef] [PubMed]

111. Sørensen, A.; Lübeck, M.; Lübeck, P.S.; Ahring, B.K. Fungal beta-glucosidases: A bottleneck in industrial use of lignocellulosic materials. Biomolecules 2013, 3, 612-631. [CrossRef]

112. Irwin, D.C.; Spezio, M.; Walker, L.P.; Wilson, D.B. Activity studies of eight purified cellulases: Specificity, synergism, and binding domain effects. Biotech. Bioeng. 1993, 42, 1002-1013. [CrossRef]

113. Wilson, D.; Irwin, D. Genetics and properties of cellulases. Adv. Biochem. Eng. Biotechnol. 1999, 65, 1-21. 
114. Kuhad, R.C.; Gupta, R.; Singh, A. Microbial cellulases and their industrial applications. Enzym. Res. 2011, 2011, 280696. [CrossRef]

115. Takashima, S.; Ohno, M.; Hidaka, M.; Nakamura, A.; Masaki, H.; Uozumi, T. Correlation between cellulose binding and activity of cellulose-binding domain mutants of Humicola grisea cellobiohydrolase I. FEBS Let. 2007, 581, 5891-5896. [CrossRef]

116. Tomme, P.; Warren, R.; Gilke, N. Cellulose hydrolysis by bacteria and fungi. Adv. Microb. Physiol. 1995, 37, 1-81.

117. Divine, C.J.; Stählberg, T.T.; Teeri, T.A.; Jones, J. High-resolution crystal structures reveal how a cellulose chain is bound in the 50 A long tunnel of cellobiohydrolase I from Trichoderma reesei. Mol. Biol. 1998, 275, 309-325. [CrossRef] [PubMed]

118. Bayer, E.A.; Belaich, J.P.; Shoham, Y.; Lamed, R. The cellulosomes: Multienzyme machines for degradation of plant cell wall polysaccharides. Annu. Rev. Microbiol. 2004, 58, 521-554. [CrossRef] [PubMed]

119. Lynd, L.R.; Weimer, P.J.; van Zyl, W.H.; Pretorius, I.S. Microbial cellulose utilization: Fundamentals and biotechnology. Microbiol. Mol. Biol. Rev. 2002, 66, 506-577. [CrossRef] [PubMed]

120. Qi, B.; Chen, X.; Su, Y.; Wan, Y. Enzyme adsorption and recycling during hydrolysis of wheat straw lignocellulose. Bioresour. Technol. 2011, 102, 2881-2889. [CrossRef] [PubMed]

121. Rosales-Calderon, O.; Trajano, H.L.; Duff, S.J. Stability of commercial glucanase and $\beta$-glucosidase preparations under hydrolysis conditions. PeerJ 2014, 2, e402. [CrossRef] [PubMed]

122. Woodward, J. Immobilized cellulases for cellulose utilization. J. Biotechnol. 1989, 11, 299-312. [CrossRef]

123. Sternberg, D.; Mandels, G.R. Regulation of the cellulolytic system in Trichoderma reesei by sophorose: Induction of cellulase and repression of beta-glucosidase. J. Bacteriol. 1980, 144, 1197-1199. [CrossRef]

124. Conn, E.E. b-Glycosidases in plants: Substrate specificity. In b-Glucosidases: Biochemistry and Molecular Biology; Esen, A., Ed.; American Chemical Society: Washington, DC, USA, 1993; pp. 15-26.

125. Javed, M.R.; Buthe, A.; Rashid, M.H.; Wang, P. Cost-efficient entrapment of $\beta$-glucosidase in nanoscale latex and silicone polymeric thin films for use as stable biocatalysts. Food Chem. 2016, 190, 1078-1085. [CrossRef]

126. Gómez, J.M.; Romero, M.D.; Fernandéz, T.M.; García, S. Immobilization and enzymatic activity of $\beta$-glucosidase on mesoporous SBA-15 silica. J. Porous Mater. 2010, 17, 657-662. [CrossRef]

127. Gómez, J.M.; Romero, M.D.; Fernandéz, T.M.; Díez, E. Immobilization of $\beta$-glucosidase in fixed bed reactor and evaluation of the enzymatic activity. Bioprocess. Biosyst. Eng. 2012, 35, 1399-1405. [CrossRef]

128. Wei, Y.; Das, S.; Berke-Schlessel, D.; Ji, H.F.; McDonough, J.; Feng, L.; Zhang, X.; Zhai, W.; Cao, Y. Synthesis of a re-usable cellobiase enzyme catalyst through in situ encapsulation in nonsurfactant templated sol-gel mesoporous silica. Top. Catal. 2012, 55, 1247-1253. [CrossRef]

129. Das, S.; Berke-Schlessel, D.; Ji, H.F.; McDonough, J.; Wei, Y. Enzymatic hydrolysis of biomass with recyclable use of cellobiase enzyme immobilized in sol-gel routed mesoporous silica. J. Mol. Catal. B Enzym. 2011, 70, 49-54. [CrossRef]

130. Guan, L.; Di, B.; Su, M.; Qian, J. Immobilization of $\beta$-glucosidase on bifunctional periodic mesoporous organosilicas. Biotechnol. Lett. 2013, 35, 1323-1330. [CrossRef] [PubMed]

131. Yiu, H.H.P.; Wright, P.A.; Botting, N.P. Enzyme immobilisation using SBA-15 mesoporous molecular sieves with functionalised surfaces. J. Mol. Catal. B Enzym. 2001, 15, 81-92. [CrossRef]

132. Reshmi, R.; Sugunan, S. Improved biochemical characteristics of crosslinked b-glucosidase on nanoporous silica foams. J. Mol. Catal. B Enzym. 2013, 85, 111-118.

133. Ivetić, D.Z.; Srdić, V.V.; Antov, M.G. Immobilization of b-glucosidase onto a mesoporous silica support: Physical and covalent binding of the enzyme. J. Serb. Chem. Soc. 2014, 79, 533-543. [CrossRef]

134. Chi, H.H.; Radu, D.R.; Dezayas, G.; Penney, M.; Lai, C.Y. Stellate MSN-based dual-enzyme nano-biocatalyst for the cascade conversion of non-food feedstocks to food products. J. Thermodyn. Catal. 2017, 8, 2.

135. Gascón, V.; Márquez-Álvarez, C.; Blanco, R.M. Successful encapsulation of $\beta$-glucosidase during the synthesis of siliceous mesostructured materials. J. Chem. Technol. Biotechnol. 2018, 93, 2625-2634. [CrossRef]

136. Califano, V.; Sannino, F.; Costantini, A.; Avossa, J.; Cimino, S.; Aronne, A. Wrinkled silica nanoparticles: Efficient matrix for $\beta$-glucosidase immobilization. J. Phys. Chem. C 2018, 122, 8373-8379. [CrossRef]

137. Califano, V.; Costantini, A.; Silvestri, B.; Venezia, V.; Cimino, S.; Sannino, F. The effect of pore morphology on the catalytic performance of $\beta$-glucosidase immobilized into mesoporous silica. Pure Appl. Chem. 2019, 91, 1583-1592. [CrossRef] 
138. Sannino, F.; Costantini, A.; Ruffo, F.; Aronne, A.; Venezia, V.; Califano, V. Covalent immobilization of $\beta$-glucosidase into mesoporous silica nanoparticles from anhydrous acetone enhances its catalytic performance. Nanomaterials 2020, 10, 108. [CrossRef]

139. Venezia, V.; Sannino, F.; Costantini, A.; Silvestri, B.; Cimino, S.; Califano, V. Mesoporous silica nanoparticles for $\beta$-glucosidase immobilization by templating with a green material: Tannic acid. Microporous Mesoporous Mater. 2020, 302, 110203. [CrossRef]

140. Zlateski, V.; Keller, T.C.; Pérez-Ramírez, J.; Grass, R.N. Immobilizing and de-immobilizing enzymes on mesoporous silica. RSC Adv. 2015, 5, 87706-87712. [CrossRef]

141. Lei, C.; Shin, Y.; Liu, J.; Ackerman, E.J. Entrapping enzyme in a functionalized nanoporous support. J. Am. Chem. Soc. 2002, 124, 11242. [CrossRef]

142. Han, H.J.; Stucky, G.D.; Butler, A. Mesoporous silicate sequestration and release of proteins. J. Am. Chem. Soc. 1999, 121, 9897-9898. [CrossRef]

143. Takimoto, A.; Shiomi, T.; Ino, K.; Tsunoda, T.; Kawai, A.; Mizukami, F.; Sakaguchi, K. Encapsulation of cellulase with mesoporous silica (SBA-15). Microporous Mesoporous Mater. 2008, 116, 601-606. [CrossRef]

144. Harmoko, C.; Sucipto, K.I.; Retnoningtyas, E.S.; Hartono, S.B. Vinyl functionalized cubic mesoporous silica nanoparticles as supporting materials to enhance cellulase enzyme stability. ARPN J. Eng. Appl. Sci. 2016, 11, 2981-2992.

145. Dadi, A.P.; Varanasi, S.; Schall, C.A. Enhancement of cellulose saccharification kinetics using an ionic liquid pretreatment step. Biotechnol. Bioeng. 2006, 95, 904-910. [CrossRef]

146. Migneault, I.; Dartiguenave, C.; Bertrand, M.J.; Waldron, K.C. Glutaraldehyde: Behavior in aqueous solution, reaction with proteins, and application to enzyme crosslinking. Biotechniques 2004, 37, 790-802. [CrossRef]

147. Kannan, K.; Jasra, R.V. Improved catalytic hydrolysis of carboxy methyl cellulose using cellulase immobilized on functionalized meso cellular foam. J. Porous Mater. 2011, 18, 409-416. [CrossRef]

148. Zhang, D.; Hegab, H.E.; Lvov, Y.; Snow, L.D.; Palmer, J. Immobilization of cellulase on a silica gel substrate modified using a 3-APTES self-assembled monolayer. SpringerPlus 2016, 5, 1-20. [CrossRef]

149. Ikeda, Y.; Parashar, A.; Bressler, D.C. Highly retained enzymatic activities of two different cellulases immobilized on non-porous and porous silica particles. Biotechnol. Bioproc. Eng. 2014, 19, 621-628. [CrossRef]

150. Chen, B.; Qiu, J.; Mo, H.; Yu, Y.; Ito, K.; Sakai, E.; Feng, H. Synthesis of mesoporous silica with different pore sizes for cellulase immobilization: Pure physical adsorption. N. J. Chem. 2017, 41, 9338-9345. [CrossRef]

151. Jannah Sulaiman, N.; Mansor, A.F.; Rahman, R.A.; Illias, R.M.; Shaarani, S.M. Adsorption kinetics of cellulase and xylanase immobilized on magnetic mesoporous silica. Chem. Eng. Technol. 2019, 42, 1825-1833. [CrossRef]

152. Lee, Y.C.; Chen, C.T.; Chiu, Y.T.; Wu, K.C.W. An effective Cellulose-to-Glucose-to-Fructose conversion sequence by using Enzyme immobilized $\mathrm{Fe}_{3} \mathrm{O}_{4}$-loaded mesoporous silica nanoparticles as recyclable biocatalysts. Chem CatChem 2013, 5, 2153-2157. [CrossRef]

153. Lee, Y.C.; Dutta, S.; Wu, K.C.W. Integrated, cascading enzyme-/chemocatalytic cellulose conversion using catalysts based on mesoporous silica nanoparticles. ChemSusChem 2014, 7, 3241-3246. [CrossRef]

(C) 2020 by the authors. Licensee MDPI, Basel, Switzerland. This article is an open access article distributed under the terms and conditions of the Creative Commons Attribution (CC BY) license (http://creativecommons.org/licenses/by/4.0/). 